\title{
A THYLAKOID POLYPEPTIDE INVOLVED IN THE RECONSTITUTION OF PHOTOSYNTHETIC OXYGEN EVOLUTION
}

\author{
by \\ BIRGER LINDBERG MØLLER 1) and PETER BORDIER HØJ1,2) \\ 1)Department of Physiology, Carlsberg Laboratory, \\ Gamle Carlsberg Vej 10, DK-2500 Copenhagen Valby \\ and \\ 2)Institute of Genetics, University of Copenhagen \\ Øster Farimagsgade 2A, DK-1353 Copenhagen K
}

Keywords: Barley, sonication, chromatofocusing, electron microscopy, sodium dodecyl sulfate polyacrylamide gel electrophoresis, variable fluorescence, histones, photosystem II. inside-out vesicles, Tris, hydroxylamine

Sonication of barley thylakoids in a high salt buffer released three polypeptides of $\mathrm{M}_{\mathrm{r}} 32,000,23,000$, and 13,500 which were purified to homogeneity by chromatofocusing.

Highly purified inside-out photosystem II preparations were obtained by French Press treatment or by Triton X100 fractionation of stacked lamellar systems. Both preparations are composed of pairs of appressed membrane sheets. In the French Press preparation, the majority of these membrane pairs are sealed whereas they are predominantly unsealed in the Triton X-100 preparation. Both preparations are able to evolve oxygen and show reversed proton pumping. The oxygen evolving capacity and variable fluorescence of both preparations were lost upon washing with high salt buffer. This treatment also removed three polypeptides at $M_{r} 32,000,23,000$, and 13,500. The inactivated preparations were reconstituted with respect to oxygen evolution and variable fluorescence by rebinding of the isolated $M_{r} 23,000$ polypeptide. The $M_{r} 32,000$ and 13,500 polypeptides had no effect on reconstitution.

Abbreviations: $\mathrm{Chl}=$ chlorophyll; chl-P = chlorophyll-protein; $\mathrm{DCCD}=$ dicyclohexyl carbodiimide: $\mathrm{DCMU}=3-$ (3,4-dichlorophenyl)-1,1-dimethylurea; $\mathrm{DCPIP}=2$,6-dichlorophenol indophenol; $\mathrm{EPR}=$ electron paramagnetic resonance; Hepes $=N$-2-hydroxyethylpiperazine- $N$-2-ethane sulfonic acid; $P P B Q=$ phenyl-p-benzoquinone; $P S=$ photosystem; SDS-PAGE = sodium dodecylsulfate polyacrylamide gel electrophoresis; TMBZ $=3.3^{\prime}, 5,5^{\prime}$ tetramethylbenzidine; Tricine $=N$-(2-hydroxy-1,1-bis(hydroxymethyl)ethyl)glycine; Tris $=$ tris-(hydroxymethyl)amino methane 


\section{INTRODUCTION}

Two different methods are available whereby an essentially complete fractionation of photosystem II from photosystem I can be achieved with retainment of the photosynthetic characteristics of photosystem II including the water splitting activity $(6,18)$. The photosystem II preparation of BERTHOLD, BABCOCK and YOCUM (6) was obtained from stacked lamellar systems of spinach by two consecutive Triton X-100 extractions and characterized by electron paramagnetic resonance (EPR) spectroscopy. Signal I $\left(P 700^{+}\right)$was absent under strongly oxidizing conditions indicating the absence of the photosystem I reaction centre. Upon Tris washing, a doubling of the light induced photosystem II signal was observed. Since this signal (Signal $\mathrm{II}_{\mathrm{f}}$ ) is thought to arise from the $P 680$ donor $\mathrm{Z}$, the result suggested that the preparation was active with respect to oxygen evolution as was also directly shown polarographically (6). Generally, the treatment of thylakoids with detergents have resulted in the loss of oxygen evolution although in a few studies $(30,46,50)$ more complex photosystem II preparations with retained oxygen evolution were obtained. The conditions of detergent fractionation designed by BERTHOLD et al. (6) thus constitutes a major improvement.

The second procedure used for the isolation of pure photosystem II vesicles was described by HeNRY and Møller (18): Chloroplasts of spinach were isolated in the presence of $10 \mathrm{~mm}$-magnesium chloride and osmotically lysed maintaining the magnesium chloride concentration. The tightly stacked lamellar systems thus obtained were subjected to repeated mechanical disruption in the French Pressure Cell. This procedure allowed the subsequent isolation of pure insideout photosystem II vesicles by phase partitioning $(1,3,25,54)$. These oxygen evolving photosystem II vesicles released protons into the ambient medium upon illumination and were enriched in the high potential form of cytochrome $b$-559. The low temperature fluorescence emission spectrum showed a major emission peak at $694 \mathrm{~nm}$ whereas the emission at $729 \mathrm{~nm}$ was weak. Four chlorophyll-proteins were contained in the photosystem II vesicle, namely chlorophyll $a$-protein $2\left(\mathrm{M}_{\mathrm{r}} 55,000\right)$, chlorophyll $a$ protein $3\left(\mathrm{M}_{\mathrm{r}} 47,000\right)$, and chlorophyll $a / b$-pro- tein 1 and $2\left(\mathrm{M}_{\mathrm{r}} 32,000\right.$ and 28,000 , respectively). Also present were four polypeptides with lower molecular weights.

Being active in photosynthetic oxygen evolution, both photosystem II preparations must contain all the polypeptides, lipids and cofactors required in this process. Much evidence suggest that manganese is essential in the oxygen evolving process $(2,12,41)$ but its mechanism of participation and site of action remains unknown. SPECTOR and WINGET (45) reported the isolation of a cholate-extractable Tris-sensitive manganese-containing polypeptide of $\mathrm{M}_{\mathrm{T}} 65,000$ which reconstituted oxygen evolution when added to the cholate-extracted thylakoid material after its incorporation into artificial liposomes. Sayre and Cheniae $(42,43)$ were unable to isolate such a manganese-containing polypeptide. NAKATANI and BARBer (38) using essentially the procedure of SPECTOR and WINGET (45) isolated a protein of molecular weight 230,000 composed of four identical subunits. This protein was also reported to restore oxygen evolution but otherwise resembled catalase. More recently, MansFIELD and BARBER (32) reported the inhibition of oxygen evolution upon washing of inside-out vesicles with 2 mM-EDTA. This treatment released manganese and polypeptides with apparent molecular weights in the range of 58,000 to 70,000 . Oxygen evolution was partially regained by addition of the released polypeptides in the presence of glycerol. The relationship of any of the EDTA released polypeptides with the reconstituting protein earlier reported (38) was not discussed. The use of inside-out vesicles in the study of the oxygen evolving enzymes was initiated by ÁKERLUND et al. (53, 55). Salt-washing of insideout vesicles inhibited oxygen evolution and resulted in the simultaneous release of polypeptides of $\mathrm{M}_{\mathrm{r}} 34,000,23,000,21,000$, and 16,000. Readdition of these polypeptides to the washed inside-out vesicles using a low salt buffer resulted in partial reconstitution of oxygen evolution. The $\mathrm{M}_{\mathrm{r}} 23,000$ polypeptide was purified from acetone extracts of thylakoids and could by itself mediate reconstitution. Preliminary studies indicated that this protein did not contain manganese. Three polypeptides of $M_{r} 34.000$, 23,000 , and 17,000 were also obtained by cholate extraction of sonicated thylakoids (47). These 
polypeptides were claimed identical to those obtained by salt washing of inside-out vesicles. After separation on a DEAE-Sephacel column, the $M_{r} 17,000$ polypeptide was found to be essential for reactivation of the extracted membranes. This protein did not contain manganese.

Using the technique of chromatofocusing, we here report on the purification to homogeneity of polypeptides released from thylakoids of barley by sonication in the presence of $200 \mathrm{~mm}$ $\mathrm{NaCl}$ (53). Among these is a polypeptide with an apparent molecular weight of 23,000 . When washed with $\mathrm{NaCl}$, both inside-out vesicles (18) and a photosystem II preparation obtained with Triton X-100 (6) were inactivated with respect to oxygen evolution and polypeptides of $\mathrm{M}_{\mathrm{r}}$ $32,000,23,000$, and 13,500 were released. Upon addition of stoichiometric amounts of the isolated $M_{r} 23,000$ polypeptide to each of the two photosystem II preparations used, both preparations were reactivated to the same extent. None of the additionally isolated polypeptides had any effect on reconstitution.

\section{MATERIALS AND METHODS}

\subsection{Solubilization of thylakoid polypeptides by sonication}

Seeds of barley (Hordeum vulgare L. cv Svalöfs Bonus) were germinated in vermiculite moistened with tap water. Seedlings were harvested after growing for 7 days at $20^{\circ} \mathrm{C}$ in continuous white light (1700 lux provided by Sylvania F48T12-GRP-VHO Gro-lux fluorescent lights). Chloroplasts were isolated in a medium composed of $400 \mathrm{~mm}$-sucrose, $20 \mathrm{~mm}-\mathrm{NaCl}$ and 50 $\mathrm{mm}$-Tricine $\mathrm{pH}$ 7.5. The chloroplasts were osmotically lysed and the lamellar systems destacked by two consecutive washings in $10 \mathrm{~mm}$ Hepes $\mathrm{pH}$ 8.3. The thylakoids were then resuspended in $200 \mathrm{~mm}-\mathrm{NaCl} / 10 \mathrm{~mm}-\mathrm{Hepes} \mathrm{pH} 8.3$ at a chlorophyll concentration of $0.6 \mathrm{mg} \cdot \mathrm{ml}^{-1}$. After stirring for $10 \mathrm{~min}$, the thylakoids were pelleted by centrifugation for $15 \mathrm{~min}$ at $48,000 \mathrm{~g}$. The washed thylakoids were resuspended in an identical volume of the $\mathrm{NaCl} / \mathrm{Hepes}$ buffer and sonicated at $4{ }^{\circ} \mathrm{C}$ for $2 \times 30 \mathrm{sec}$ in a MSE MK2 Sonicator fitted with a $10 \mathrm{~mm}$ probe and adjusted to a peak to peak amplitude of 18 microns. The solubilized thylakoid polypeptides were sep- arated from the depleted thylakoids by centrifugation for $30 \mathrm{~min}$ at $116.000 \mathrm{~g}$. Sodium dodecyl sulfate polyacrylamide gel electrophoresis (SDS-PAGE) revealed the preferential extraction of three polypeptides at $\mathrm{M}_{\mathrm{r}}$ $32,000,23,000$, and 13,500 . All operations were carried out at $0-4{ }^{\circ} \mathrm{C}$.

\subsection{Isolation of polypeptides for reconstitution experiments}

The supernatant containing the polypeptides solubilized by sonication in $200 \mathrm{~mm}-\mathrm{NaCl} / 10$ mM-Hepes (conductivity $23 \mathrm{mS}$ ) was dialysed against $25 \mathrm{~mm}$-imidazol $\mathrm{pH} 6.2$ for 2 hours to decrease its conductivity to around $6 \mathrm{mS}$ corresponding to approx. $50 \mathrm{~mm}-\mathrm{NaCl}$. Centrifugation for $10 \mathrm{~min}$ at $48,000 \mathrm{~g}$ produced a tiny green pellet and an almost colorless clear supernatant which was fractionated by chromatofocusing on a column $(1.0 \times 30 \mathrm{~cm})$ containing Polybuffer exchanger PBE 94 (Pharmacia Fine Chemicals,

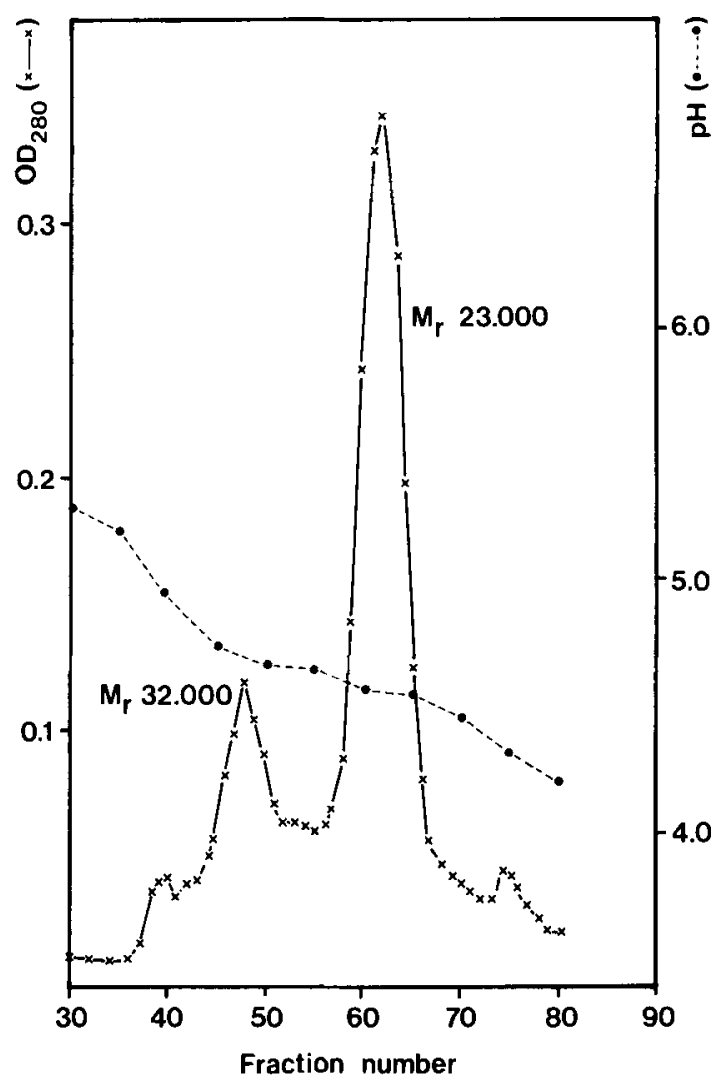

Figure 1. Fractionation of the $M_{r} 32,000$ and 23,000 polypeptides by chromatofocusing. 


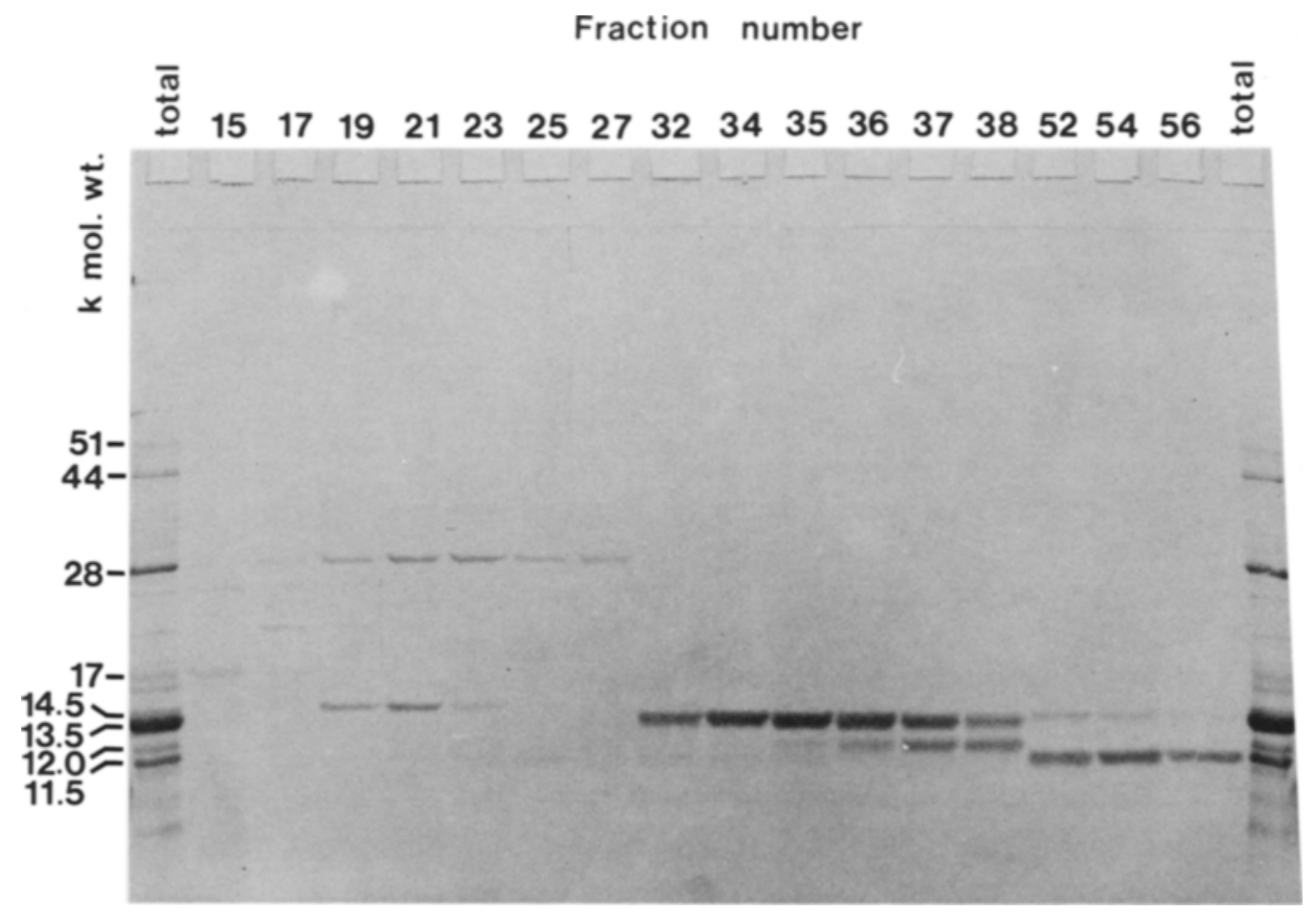

Figure 2: Isolation of the $M_{r} 13,500$ polypeptide by cation exchange chromatography.

Polypeptides released by thylakoids by sonication in the presence of $200 \mathrm{mM}-\mathrm{NaCl}$ and which did not bind to the chromatofocusing column were applied to a $\mathrm{CM}$ Sepharose $\mathrm{Cl} 6 \mathrm{~B}$ column and eluted using a linear salt gradient (section 2.2). Pure $M_{r} 13,500$ polypeptide was obtained in fractions 32-34. For convenience, the $M_{r} 13,500$ polypeptide is assigned as $13 \mathrm{k}$ in subsequent figure legends.

Uppsala, Sweden) previously equilibrated with 25 mm-imidazole $\mathrm{pH}$ 6.2. Elution was carried out using a 1:10 dilution of Polybuffer PB 74 at $\mathrm{pH} 4.0$ using a flow rate of $3 \mathrm{ml} \cdot \mathrm{min}^{-1}$. The presence of polypeptides in the run-off and in the collected fractions $(3 \mathrm{ml})$ was monitored by SDS-PAGE: Fractions containing either the $M_{r}$ 32,000 or the 23,000 polypeptide as the only component were pooled (Figure 1). Those fractions which contained mixtures of the two polypeptides were pooled, adjusted to $\mathrm{pH} 6.2$ with 1 $\mathrm{M}$-Hepes $\mathrm{pH} 7.5$, and rechromatofocused at identical conditions. The homogenous preparations of the $M_{r} 23,000$ and of the $M_{r} 32,000$ polypeptides were stored at $-80{ }^{\circ} \mathrm{C}$ without removal of the Polybuffer.

The $M_{r} 13,500$ polypeptide did not bind to the chromatofocusing column. To obtain this polypeptide, the run-off was concentrated to a small volume, diluted 10 -fold with $10 \mathrm{~mm}$-Hepes $\mathrm{pH}$
7.5 and fractionated on CM Sepharose $\mathrm{Cl}$ 6B $(2.5 \times 5 \mathrm{~cm})$ using a $500 \mathrm{ml}$ linear $\mathrm{NaCl}$-gradient of 0-600 mu in $10 \mathrm{~mm}$-Hepes $\mathrm{pH} 7.5$. The flow rate was $0.3 \mathrm{ml} \cdot \mathrm{min}^{-1}$ and $5 \mathrm{ml}$ fractions were collected. This method provided a homogenous preparation of the $M_{r} 13,500$ polypeptide (Figure 2).

\subsection{Preparation of inside-out photosystem II vesicles}

Mechanical disruption of the photosynthetic lamellar systems and subsequent fractionation was carried out using a French Pressure Cell and phase-partitioning in an aqueous two phase dextran/polyethylene glycol system (18). The French Press was operated at $3,600 \mathrm{lb} \cdot \mathrm{in}^{-2}$ and the polymer concentration used was $5.80 \%(20)$. The inside-out photosystem II vesicles partitioned to the bottom phase, and were repartitioned with fresh upper phase until essentially all chlorophyll 

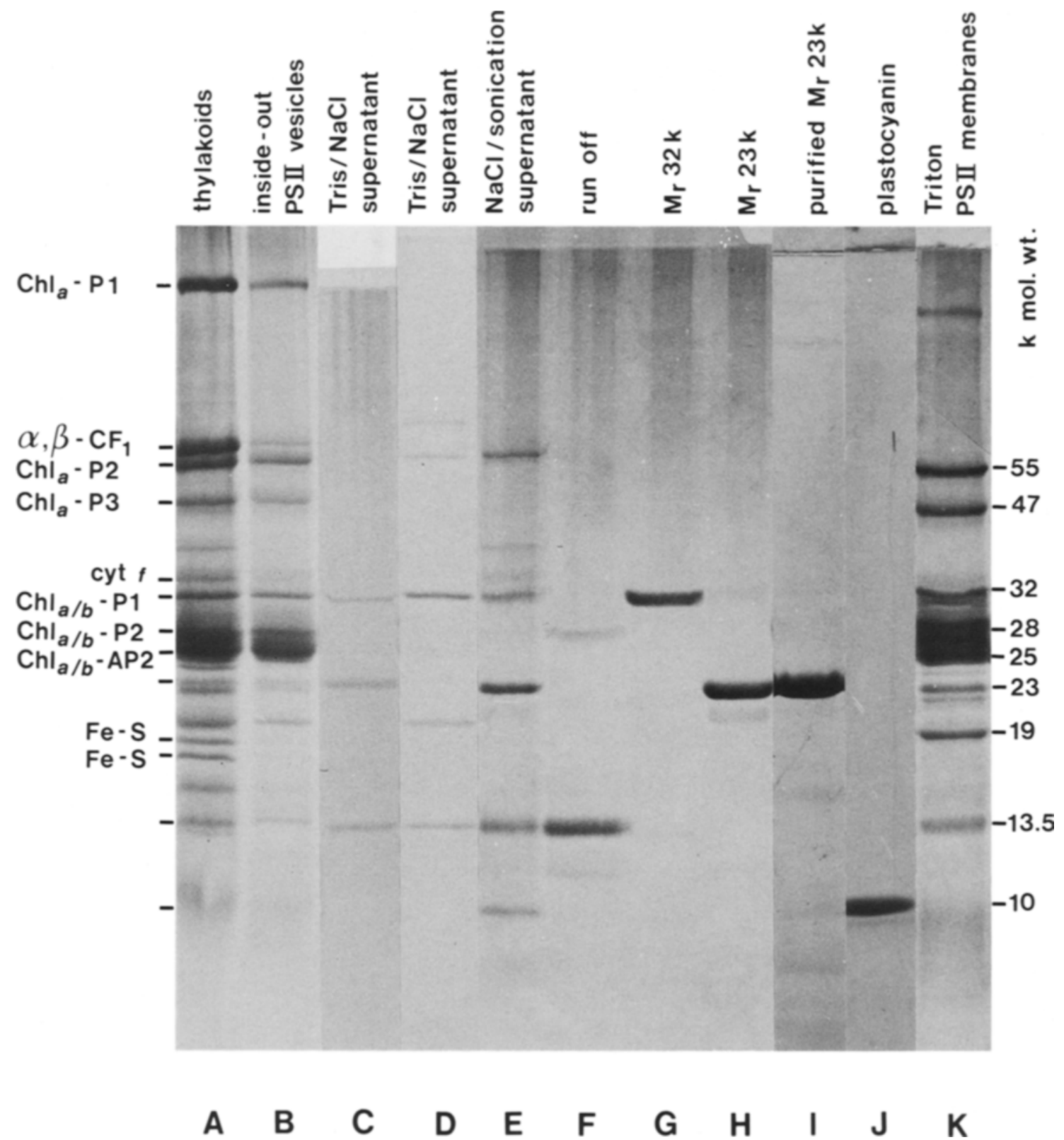

Figure 3: Polypeptide composition of inside-out photosystem II vesicles and of photosystem II membranes prepared with Triton $\mathrm{X}-100$ and of the polypeptides released by Tris/ $\mathrm{NaCl}$ washing or from thylakoids by sonication in the presence of $\mathrm{NaCl}$.

The electrophoretic separation was carried out at $10^{\circ} \mathrm{C}$ on a denaturing dodecyl sulfate containing $11-15 \%$ linear gradient polyacrylamide gel (system II in (31)). A: thylakoids. B:inside-out photosystem II vesicles. C and D: polypeptides released upon washing the inside-out vesicles with $200 \mathrm{~mm}-\mathrm{NaCl} / 50 \mathrm{~mm}$ - Tris pH 8.3 and illustrating the variability in the electrophoretic properties of the $\mathrm{M}_{\mathrm{r}}$ polypeptide in different experiments. E: polypeptides released upon sonication of thylakoids in the presence of $200 \mathrm{mM}-\mathrm{NaCl} / 10 \mathrm{~mm}-\mathrm{Hepes} \mathrm{pH}$ 8.3. F: polypeptides in $\mathrm{E}$ which did not bind to the chromatofocusing column. $G$ : $M_{r} 32,000$ polypeptide after chromatofocusing. $H: M_{r}$ 23.000 polypeptide after chromatofocusing. I: $\mathrm{M}_{\mathrm{r}} 23,000$ polypeptide after re-chromatofocusing. J: plastocyanin eluted from the chromatofocusing column at $\mathrm{pH} 4.0$ after application of a salt gradient. K: photosystem II membranes prepared with Triton X-100. 
Table I.

Reconstitution of oxygen evolution by rebinding of isolated polypeptides to sodium chloride washed inside-out vesicles.

\begin{tabular}{|c|c|c|c|c|c|}
\hline & & $\begin{array}{l}\text { Oxygen evolution } \\
\text { /moles } \mathrm{O}_{2} / \mathrm{mg} \mathrm{chl} / \mathrm{hr}\end{array}$ & $\begin{array}{c}\text { Inhibition } \\
\%\end{array}$ & $\begin{array}{c}\text { Stimulation } \\
\%\end{array}$ & $\begin{array}{c}\text { Reconstitution } \\
\%\end{array}$ \\
\hline Untreated & & 260 & & & \\
\hline \multirow[t]{4}{*}{$\mathrm{NaCl}$ washed } & & 32 & 88 & & \\
\hline & $+\mathrm{M}_{\mathrm{r}} 23,000$ & 169 & & 428 & 65 \\
\hline & $+\mathrm{M}_{\mathrm{r}} 13,500+23,000+32,000$ & 180 & & 462 & 69 \\
\hline & $+M_{r} 13,500+32,000$ & 35 & & 9 & 3 \\
\hline
\end{tabular}

containing material remained in the dextranrich bottom phase. The vesicles were collected from the dextran phase by ultracentrifugation, resuspended in a medium composed of $500 \mathrm{~mm}$ sucrose, $3 \mathrm{~mm}-\mathrm{NaCl}$ and $10 \mathrm{~mm}$-Hepes $\mathrm{pH} 7.5$. All experiments were carried out with freshly isolated vesicles.

\subsection{Preparation of photosystem II membranes using Triton X-100}

The procedure of BERTHOLD et al. (6) was used: Barley chloroplasts were prepared in a medium composed of $400 \mathrm{~mm}-\mathrm{NaCl}, 2 \mathrm{~mm}-\mathrm{MgCl}_{2}$, and $20 \mathrm{~mm}$-Tricine pH 8.0. The chloroplasts were osmotically lysed by two washings in $5 \mathrm{~mm}-\mathrm{MgCl}_{2} /$ $15 \mathrm{~mm}-\mathrm{NaCl} / 20 \mathrm{~mm}$-Hepes $\mathrm{pH}$ 7.5. The tightly stacked lamellar systems obtained were resuspended in the same medium at $2 \mathrm{mg} \mathrm{chl} \cdot \mathrm{ml}^{-1}$ and incubated with Triton X-100 (25 mg $\mathrm{chl} \cdot \mathrm{ml}^{-1}$ ) at $4{ }^{\circ} \mathrm{C}$ for $30 \mathrm{~min}$ with stirring. Centrifugation for $30 \mathrm{~min}$ at $48,000 \mathrm{~g}$ provided a grana enriched pellet which again was resuspended in the same medium at $2 \mathrm{mg} \mathrm{chl} \cdot \mathrm{ml}^{-1}$. Triton X-100 was added $\left(5 \mathrm{mg} \cdot \mathrm{mg}^{-1} \mathrm{chl}\right)$ after which centrifugation ( $30 \mathrm{~min}$ at $48,000 \mathrm{~g}$ ) of the suspension was immediately started. The pellet thus obtained is composed of oxygen evolving photosystem II membranes and was resuspended in $400 \mathrm{~mm}$-sucrose $/ 5 \mathrm{~mm}-\mathrm{MgCl}_{2} / 15 \mathrm{~mm}$ $\mathrm{NaCl} / 20$ mм-Hepes $\mathrm{pH} 7.5$. Freshly isolated material or aliquots which had been stored at $-80^{\circ} \mathrm{C}$ were used in the experiments.

\subsection{Sodium chloride washing of the photosystem II preparations.}

Inside-out photosystem II vesicles or photosystem II preparations obtained with Triton X100 were resuspended in $200 \mathrm{~mm}-\mathrm{NaCl} / 10 \mathrm{~mm}$ -
Hepes $\mathrm{pH} 8.3$ at $0.062 \mathrm{mg} \mathrm{chl} \cdot \mathrm{ml}^{-1}$. After stirring for $20 \mathrm{~min}$ in the dark, the vesicles were pelleted by centrifugation for $15 \mathrm{~min}$ at 116,000 g. The polypeptide composition of the supernatant and of the pellet was monitored by SDSPAGE. The pellet was resuspended $(1 \mathrm{mg}$ $\mathrm{chl} \cdot \mathrm{ml}^{-1}$ ) in $500 \mathrm{~mm}$-sucrose $/ 3 \mathrm{~mm}-\mathrm{NaCl} / 10$ mm-Hepes pH 7.5 (subsequently referred to as "low salt buffer") and immediately used for reconstitution experiments.

\subsection{Preparation of reconstituted vesicles}

Purified polypeptides or the mixture of polypeptides released upon $\mathrm{NaCl}$ washing were combined with the photosystem II preparations inactivated by $\mathrm{NaCl}$ washing. After standing for 5 min, the reactants were diluted 50 fold with "low salt buffer". The photosystem II membranes were then pelleted by centrifugation (15 $\mathrm{min}$ at $116,000 \mathrm{~g}$ ), resuspended in the same buffer at a chlorophyll concentration of $1 \mathrm{mg} \cdot \mathrm{ml}^{-1}$ and assayed for their capacity to evolve oxygen and for rebound polypeptides.

\subsection{Photochemical assays}

Oxygen evolution was assayed polarographically at $18^{\circ} \mathrm{C}$ in a Rank Brothers oxygen electrode (Rank Bros., Bottisham, Cambridge, U.K.). The assay medium was $70 \mathrm{~mm}$-sucrose $/ 3$ $\mathrm{mm}-\mathrm{NaCl} / 30 \mathrm{~mm}-\mathrm{Hepes} \mathrm{pH} 6.5$, supplemented with $0.5 \mathrm{~mm}$-phenyl-p-benzoquinone as electron acceptor. The total volume of the reaction mixture was $3.0 \mathrm{ml}$ and an amount of photosystem II vesicles corresponding to $60 \mu \mathrm{g}$ chlorophyll was used in each experiment. Rate saturating irradiation of the reaction mixture was provided by a Schott KL 150 B light source fitted with a light pipe $(\Phi 8 \mathrm{~mm})$. Simultaneous measurements of 
oxygen evolution and proton gradient formation were carried out as in (18).

Measurement of room temperature fluorescence induction was carried out in a four-sided cuvette placed in a light-tight holder fitted with a quartz cylinder mounted on a bifurcated lightpipe to allow excitation of the sample with a broad band of blue light (Corning 4-96 filter) and collection of the emitted fluorescence (Corning 2-64 filter). The assay mixture was composed of $70 \mathrm{~mm}$-sucrose/3 mm-NaCl/30 mm-Hepes $\mathrm{pH}$ 6.5. The total volume was $300 \mu \mathrm{l}$ and an amount of photosystem II membranes containing $9 \mu \mathrm{g}$ chlorophyll was used for each experiment. Each sample was dark equilibrated for $10 \mathrm{~min}$. The onset of irradiation was controlled by a photographic Compur Electronic 1 shutter having an opening time of $0.6 \mathrm{msec}$. The fluorescence signal was measured using a Hamamatsu R928 photomultiplier and a signal amplifier (Applied Photophysics, London) and recorded on a digital oscilloscope (Nicolet Explorer II Digital Osscilloscope, Madison, Wisconsin). Low temperature fluorescence emission spectra were obtained as in (44).

\subsection{Gel-electrophoresis}

Sodium dodecyl sulfate polyacrylamide gel electrophoresis (SDS-PAGE) was carried out at $10{ }^{\circ} \mathrm{C}$ using a $6 \%$ stacking gel and a $11-15 \%$ linear polyacrylamide gradient separation gel (System II in (31)). Non-denaturing polyacrylamide gel electrophoresis was carried out using a $4.5 \%$ stacking gel and a $6.6 \%$ separation gel (11). Flatbed isoelectric focusing in polyacrylamide gels was performed as described in (23). After the electrophoretic fractionation, the gels were stained with Coomassie Brilliant Blue R250.

\subsection{Electron microscopy}

Samples for electron microscopy were incubated for 2 hours at room temperature with $4 \%$ redistilled glutaraldehyde. Post-fixation was carried out in $2 \%$ osmium tetroxide dissolved in 60 mM-potassium phosphate pH 7.4 for 3 hours. Each fixative was removed by repeated cycles of centrifugation and resuspension in $60 \mathrm{~mm}$-potassium phosphate. The specimen was subsequently washed with distilled water and then stained for 3 hours at $60{ }^{\circ} \mathrm{C}$ with $2 \%$ uranyl acetate. Dehydration was carried out by resuspending the specimen in solutions of increasing ethanol content $(30,50,75,90,96,99,99$, and $99 \%$ ), propylene oxide and mixtures of propylene oxide/Spurr resin. The specimen was finally embedded in pure Spurt resin which was polymerized for 8 hours at $70{ }^{\circ} \mathrm{C}$. The cut sections were placed on copper grids and re-stained with uranyl acetate/ lead citrate for $30 \mathrm{~min}$ using the LKB Ultrostainer System Carlsberg and examined in the electron microscope (Siemens Elmiscope 102) at $80 \mathrm{kV}$.

\subsection{Additional analytical procedures}

Chlorophylls were determined in $80 \%$ acetone and quantified according to ARNON (4). Amino acid analysis was carried out after hydrolysis of the protein in $5.7 \mathrm{~N}-\mathrm{HCl}$ at $110^{\circ} \mathrm{C}$ for 24 hours in evacuated sealed tubes. Manganese determinations were carried out by atomic absorption spectrometry at $279,5 \mathrm{~nm}$ using a Perkin-Elmer 2380 Atomic Absorption Spectrometer fitted with a HGA 74 graphite tube and Autosampler ASE.

\section{RESULTS AND DISCUSSION}

\subsection{Sonication of thylakoids and the isolation of released polypeptides}

Sodium chloride washing of inside-out vesicles results in the inhibition of oxygen evolution and in the release of polypeptides at $\mathrm{M}_{\mathrm{r}} 34,000$, 23,000 and 16,000 (55). In thylakoids of normal side orientation, these polypeptides are electrostatically bound to the inner thylakoid surface and therefore not released into the medium upon washing with sodium chloride. The yield of inside-out vesicles is low, especially when vesicles of simple polypeptide composition are desired $(18,19)$. The use of these vesicles as starting material for isolation of polypeptides located on the inner thylakoid surface will therefore only provide low amounts. Consequently, we developed an alternative approach towards the isolation of such polypeptides avoiding any use of detergents or extractions with organic solvents.

The isolated lamellar systems were washed twice with $10 \mathrm{~mm}$-Hepes $\mathrm{pH} 8.3$ to destack the membranes. Thereafter, the membranes were washed once with a buffer of high ionic strength 
(200 mM-NaCl, $10 \mathrm{~mm}$-Hepes $\mathrm{pH} 8.3$ ). This is expected to restack portions of the membranes and to remove extrinsic proteins like chloroplast coupling factor. The same polypeptides as those obtained from inside-out vesicles were now preferentially released from the washed thylakoids by sonication in the same buffer of high ionic strength. SDS-PAGE of the polypeptides released by sonication revealed major bands at $\mathrm{M}_{\mathrm{r}}$ $32,000,23,000$ and 13,500 plus four additional components (Figure 3, lane E). In comparison, the procedure used by ẢKERLUND et al. (55) extracted about 23 components. When the polypeptides released by sonication were added to $\mathrm{NaCl}$-washed inside-out vesicles in a low salt medium, reconstitution of oxygen evolving capacity was observed (Table I). To determine the polypeptide components active in the reconstitution process, the polypeptides were fractionated by chromatofocusing. A clean separation of the $M_{r}$ 32,000 and 23,000 polypeptides was achieved (Figure 1) although their $\mathrm{pH}$ of elution differed less than $0.2 \mathrm{pH}$ units. Due to the buffering capacity of the proteins, the $\mathrm{pH}$ gradient (Figure 1) becomes more shallow near their elution points of $\mathrm{pH} 4.70$ and 4.55. The isoelectric point of the $M_{r} 23,000$ polypeptide was measured as 5.1 by isoelectric focusing (23). Upon loading of the chromatofocusing column, the top of the gel gradually became blue. This blue band was retained during elution of the $M_{r} 32,000$ and 23,000 polypeptides. Maintaining the $\mathrm{pH}$ at 4.0, the blue component was eluted using a linear salt gradient ( $0-1000 \mathrm{~mm})$. It was identified by its absorption spectrum as plastocyanin (27) and showed only one band at $M_{r} 10.000$ when analyzed by SDS-PAGE (Figure 3, lane J). Plastocyanin is known to be localized at the inside of the thylakoid membrane and to be released by sonication (17).

The run-off from the chromatofocusing column contained the $M_{r} 13,500$ polypeptide and was desalted by pressure filtration and fractionated by cation exchange chromatography (Figure 2). This provided a clean preparation of the $M_{r} 13,500$ polypeptide. Some of the minor components released by sonication were also obtained as pure polypeptides (Figure 2). It was found that concentration of the extracts prior to fractionation by chromatofocusing either by pressure filtration or by dialysis and lyophilization greatly reduced the yields. Gel filtration of the extracts also gave rise to the appearance of an $M_{r} 20,000$ species with a simultaneous loss of the $M_{r}$ 23,000 polypeptide. Variability in the electrophoretic mobility of the $M_{\tau} 23,000$ polypeptide can also be observed immediately after washing of inside-out vesicles with $200 \mathrm{~mm}$ $\mathrm{NaCl} / 50 \mathrm{~mm}$-Tris pH 8.5 (Figure 3, lanes C,D). The separation method here designed using chromatofocusing avoids these problems.

\subsection{Characterization of the photosystem II preparations used}

The polypeptide composition of purified photosystem II inside-out vesicles obtained from spinach was reported earlier $(18,19)$. Inside-out photosystem II vesicles from barley (Figure 3 ) had a similar composition although they were always contaminated to some extent with photosystem I components (20). Electron microscopy revealed that the preparation consisted of pairs of tightly appressed membrane sheets with only a limited volume at the edges (49). The photosystem Il membranes prepared with Triton X100 as reported by BERTHOLD et al. (6) have not previously been characterized with respect to their polypeptide composition and ultrastructure. SDS-PAGE revealed the presence of four chlorophyll-proteins, chlorophyll a-proteins 2 and 3, and chlorophyll $a / b$-proteins 1 and 2 . A faint green band with an electrophoretic mobility slightly different from that of chlorophyll $a$ protein 1 was also observed in addition to four polypeptides at $M_{r} 23,000,21,500,19,000$ and 13,500 . Although some of the bands may contain more than one polypeptide species, the composition of these vesicles is remarkable simple and compares well with that of inside-out vesicles of spinach $(18,19)$. The EPR characteristics of the preparation (6) thus agree with an essentially complete absence of photosystem I polypeptide components. The low temperature fluorescence emission spectrum of the Triton X-

Figure 4: Electron micrographs of the photosystem II membranes prepared with Triton X-100.

The arrows indicate the presence of pairs of appressed membrane sheets not sealed at their edges. 


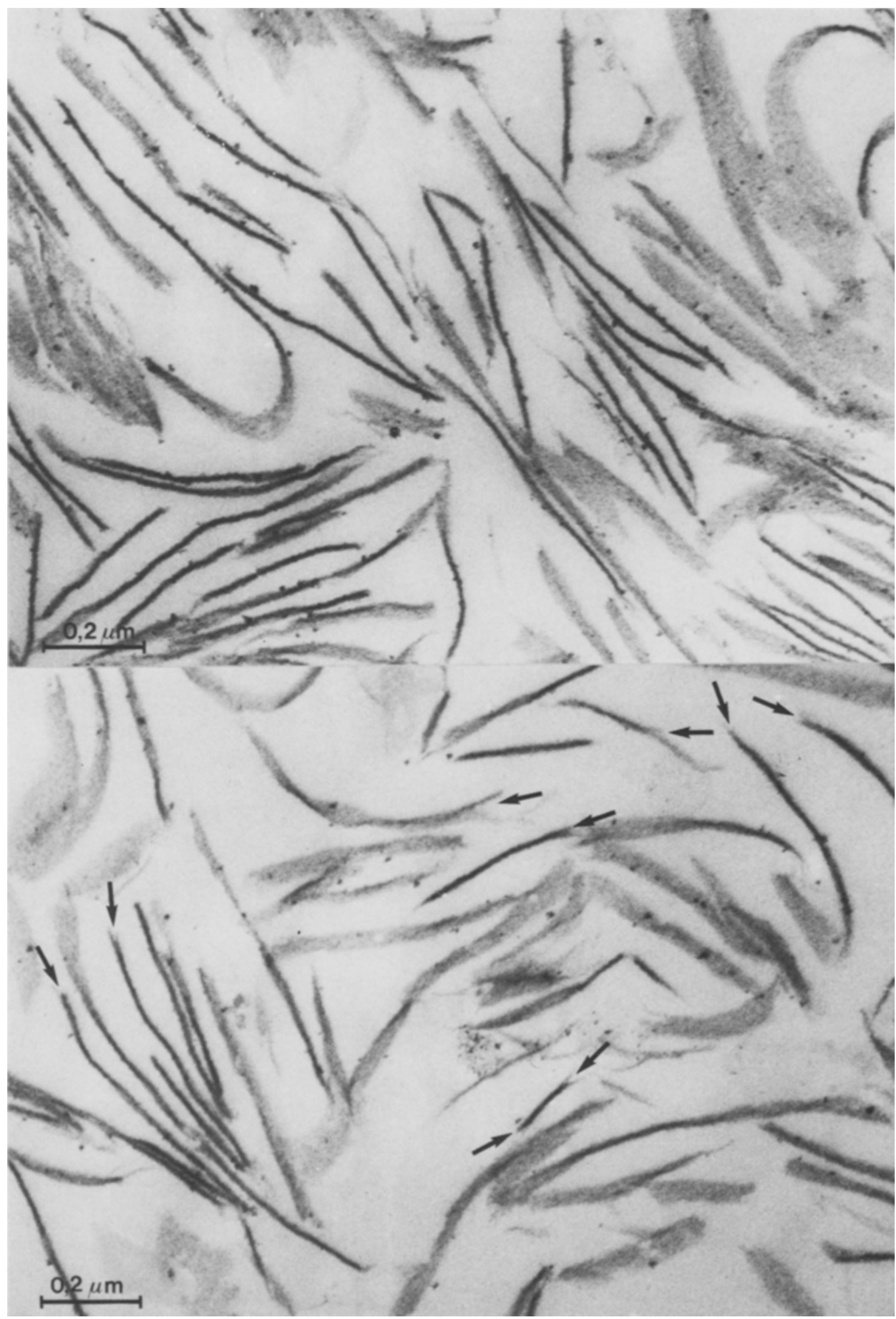


100 preparation (Figure 5) was also similar to that of the inside-out vesicles (18) revealing a strong depletion of the long wavelengths components which are generally associated with photosystem I antennae pigments (16). Electron micrographs of the Triton X-100 photosystem II preparation reveal a homogenous preparation of tightly appressed pairs of membrane sheets of similar size to those observed in the preparation of inside-out photosystem II vesicles. Whereas the inside-out photosystem II vesicles appeared to be sealed along their edges, as evidenced by the presence of a non-appressed region of membrane connecting the two membrane sheets, several of the photosystem II membrane sheets prepared with Triton X-100 are not. Instead two non-appressed bluntly ending short membrane regions diverge at the edges (Figure 4). Probably the bound Triton X-100 stabilizes this conformation. The almost identical composition and appearance of the two photosystem II preparations makes it most likely that the Triton $\mathrm{X}$ 100 photosystem II membranes are also insideout vesicles. Direct measurements of the proton pumping capacity of the preparation indeed demonstrated an acidification of the surrounding medium upon illumination. During the preparation of the vesicles and their fixation for

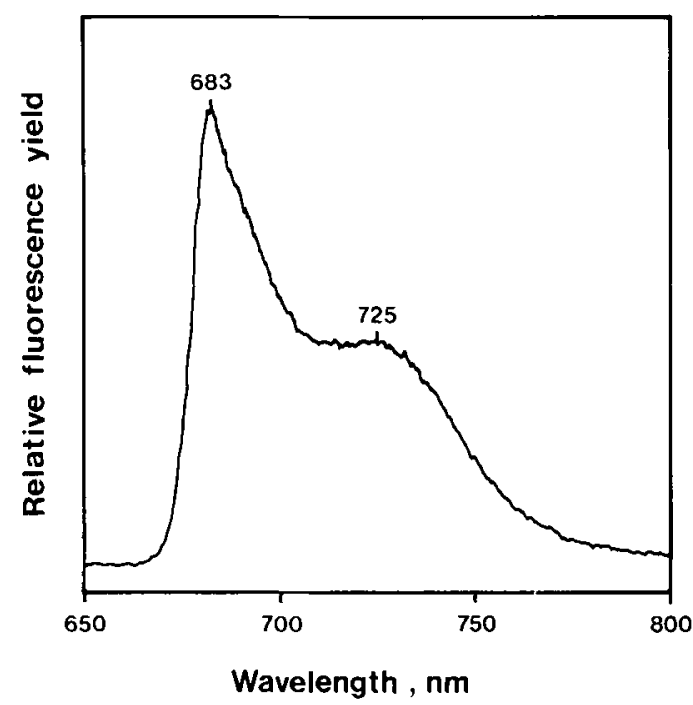

Figure 5. Low temperature $(77 \mathrm{~K})$ fluorescence emission spectrum of photosystem II membranes prepared with Triton X-100. electron microscopy, the concentrations of divalent cations $\left(\mathrm{Mg}^{2+}\right)$ was maintained at $5 \mathrm{~mm}$. As judged by SDS-PAGE, removal of the stroma thylakoids takes place primarily with the first Triton X-100 treatment. Solubilization of the grana stacks by Triton $\mathrm{X}-100$ occurs by breakage of the exposed non-appressed regions at their sides which facilitates the formation of insideout vesicles (25). The extent to which these appressed membrane sheets are sealed cannot be evaluated. Digitonin treatment of stacked lamellar systems in the presence of $5 \mathrm{~mm}-\mathrm{MgCl}_{2}$ can produce tightly appressed membrane pairs of similar appearance recognized as inside-out vesicles by GEROLA et al. (14). On a chlorophyll basis, the yield of inside-out vesicles and the Triton $X$ 100 vesicles are about 8 and $45 \%$, respectively. Considering the additional much more elaborate preparation procedure involved in obtaining inside-out vesicles, the Triton X-100 preparation of BERTHOLD et al. (6) is clearly preferable for experimental work where the presence of Triton X100 causes no interference. It is likely that also digitonin fractionation (14) can be optimized to yield pure inside-out photosystem II membrane preparations.

\subsection{Reconstitution of oxygen evolution by re- binding of purified polypeptides to depleted membranes}

The polypeptide pattern of lamellar systems subjected to sonication in the presence of $\mathrm{NaCl}$ reveals a complete depletion of the $M_{r} 23,000$ polypeptide (Figure 6). The depletion in the $M_{r}$ 32,000 and 13,500 region is less obvious and variable. Following the sonication procedure, the membranes are inactive in oxygen evolution. Readdition of purified polypeptides to the depleted thylakoid membranes was carried out in a low salt buffer (section 2.6.). After standing for 5 min, the reaction mixture was diluted 50 fold with the low salt buffer and centrifuged. The presence of the added polypeptide in the pellet would then demonstrate its rebinding to the depleted membrane. Rebinding was again most clearly visible with respect to the $M_{r} 23,000$ polypeptide, and rebinding experiments including this protein partially reconstituted oxygen evolution. Due to the complex polypeptide composition of the sonicated thylakoids, quantitative 


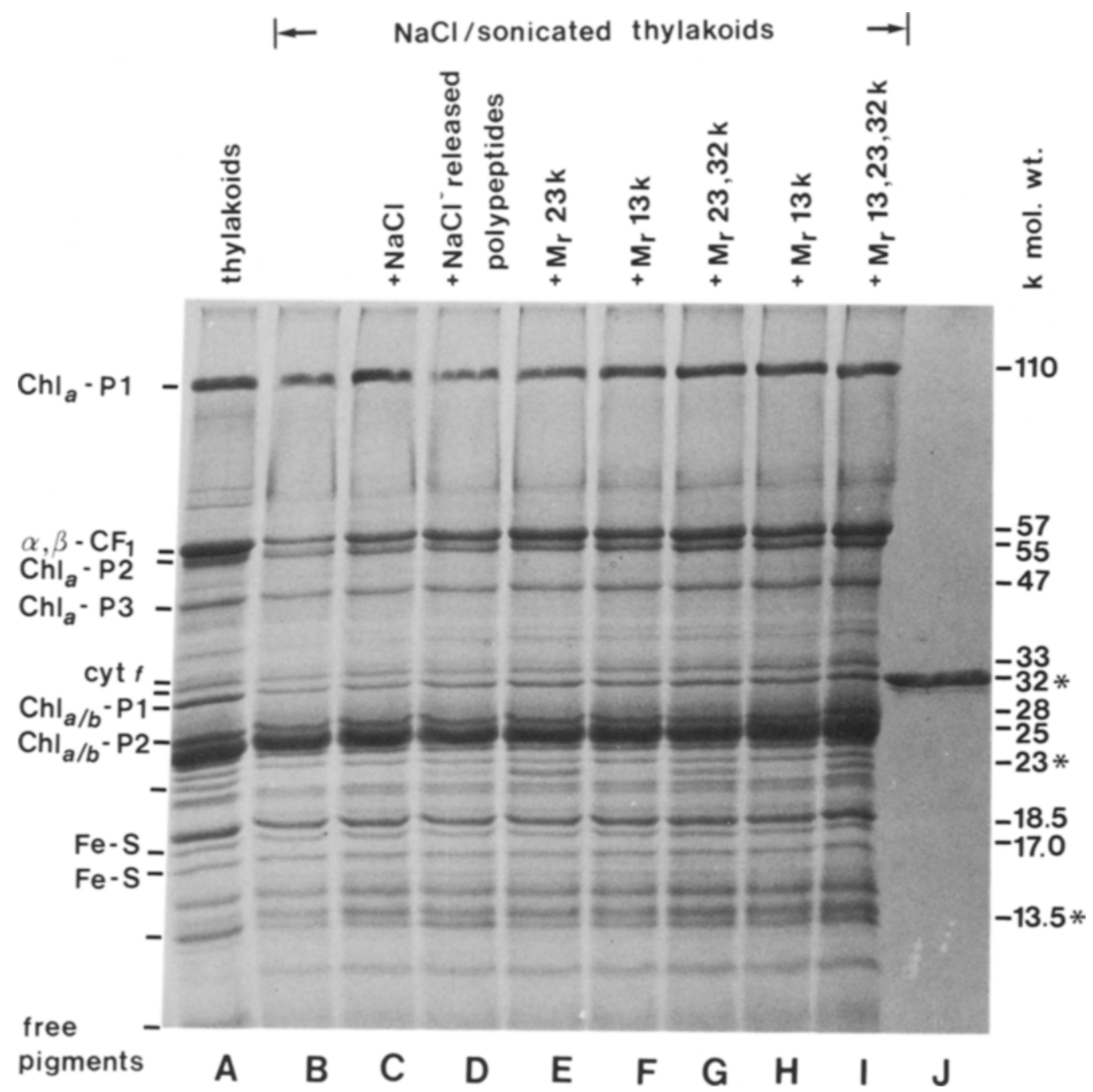

Figure 6. Rebinding of purified polypeptides to depleted thylakoid membranes.

The depleted thylakoids were obtained as a pellet after sonication of thylakoids in the presence of $200 \mathrm{~mm}-\mathrm{NaCl}$ / $10 \mathrm{~mm}$-Hepes pH 8.3. A: thylakoids. B: depleted thylakoids. C: as in "B" plus $\mathrm{NaCl}$. D: as in "B" after rebinding of $\mathrm{NaCl}$-released polypeptides. $\mathrm{E}$ : as in " $\mathrm{B}$ " after rebinding of $\mathrm{M}_{\mathrm{r}} 23,000$ polypeptide. $\mathrm{F}$ : as in " $\mathrm{B}$ " after rebinding of $M_{r} 13,500$ polypeptide. $G$ : as in "B" after rebinding of $M_{r} 23,000$ and 32,000 polypeptides. $H$ : as "F". $I$ : as "B" after rebinding of $M_{r} 13,500,23,000$, and 32,000 polypeptides. $J$ : purified $M_{r} 32,000$ polypeptide. The preparation of the $M_{r} 13,500$ polypeptide used for the binding studies was the run-off fraction from the chromatofocusing column. The electrophoretic conditions are as described in legend to Figure 3.

measurements on the reconstitution of oxygen evolution was carried out using purified photosystem II membranes (section 3.2). In all the reconstitution experiments here reported, readdition of polypeptides to the $\mathrm{NaCl}$ washed photosystem II vesicles was always followed by extensive dilution with the low salt buffer and cen- trifugation. Measurements of oxygen evolution were then carried out on the pelleted membranes. This method ensured that the assay conditions were identical in each experiment. This is important because earlier studies have shown that the extent of reconstitution is strongly affected by the amount of e.g. $\mathrm{NaCl}$ (22), glycerol 
Table II.

Reconstitution of oxygen evolution by rebinding of isolated polypeptides to sodium chloride washed photosystem II membranes prepared with Triton X-100.

\begin{tabular}{|c|c|c|c|c|c|}
\hline & & $\begin{array}{l}\text { Oxygen evolution } \\
\text { moles } \mathrm{O}_{2} / \mathrm{mg} \mathrm{chl} / \mathrm{hr}\end{array}$ & $\begin{array}{c}\text { Inhibition } \\
\%\end{array}$ & $\begin{array}{c}\text { Stimulation } \\
\%\end{array}$ & $\begin{array}{c}\text { Reconstitution } \\
\% \\
\end{array}$ \\
\hline Untreated & & 239 & & & \\
\hline \multirow{6}{*}{$\mathrm{NaCl}$ washed } & & 15 & 94 & & \\
\hline & $+\mathrm{M}_{\mathrm{r}} 23,000$ & 128 & & 753 & 54 \\
\hline & $+M_{r} 13,500+23,000+32,000$ & 134 & & 793 & 56 \\
\hline & $+M_{r} 13,500$ & 20 & & 33 & 8 \\
\hline & $+\mathrm{M}_{\mathrm{r}} 32,000$ & 25 & & 66 & 10 \\
\hline & $+M_{r} 13,500+32,000$ & 20 & & 33 & 8 \\
\hline
\end{tabular}

$(32,47)$ and ethylene glycol $(42,43)$ present.

Inside-out photosystem II vesicles and photosystem II membranes prepared with Triton X100 are about equally active with respect to oxygen evolution (Tables I and II, respectively). The rates here reported for the inside-out photosystem II vesicles are about three times higher than earlier reported (18). The main reason for this is the use of sucrose $/ \mathrm{NaCl} / \mathrm{Hepes}$ at $\mathrm{pH} 6.5$ instead of sodium phosphate at $\mathrm{pH} 7.0$ as assay buffer. Similar rates to those obtained here with the Triton X-100 preparation were reported by BERTHOLD et al. (6). The pH optimum for both photosystem II preparations used is about 6.5 and thus considerably lower than for thylakoids. In a recent study, lowering the $\mathrm{pH}$ of the isolation buffers to $\mathrm{pH} 6.0$ was reported to double the rates of oxygen evolution obtained with the Triton X-100 preparation (15).

Both types of photosystem II preparations are sensitive towards washing with $200 \mathrm{~mm}-\mathrm{NaCl} / 10$ mM-Hepes pH 8.3. To obtain maximal inhibition of oxygen evolution, the salt washing step had to be carried out in the dark and at an elevated $\mathrm{pH}$. The same two parameters determine the degree of inhibition after Tris and hydroxylamine treatment $(10,13,15)$. Typically a $90 \%$ inhibition of oxygen evolution was observed, whereas ÅKERLUND et al. (55) maximally obtained $74 \%$. As judged by SDS-PAGE (Figure 7), the salt wash of the Triton X-100 preparation completely removes the $M_{r} 23,000$ polypeptide and to a somewhat lower extent the $M_{r} 32,000$ and 13,500 polypeptides. The same result was obtained using inside-out vesicles. Whereas the
$M_{r}$ 23,000 polypeptide seems to be completely removed in our study (Figure 7), the extent of depletion observed by ÅKERLUnd et al. (53, Figure 3) does not appear pronounced in that their inside-out vesicles contained a large number of polypeptides not necessarily resolved by the gel system used. However, using our gel system, even the polypeptide pattern of the thylakoid pellet obtained after sonication in the presence of 200 mM-sodium chloride revealed no polypeptide band at the position of the $M_{r} 23,000$ polypeptide (Figure 6).

Reconstitution of oxygen evolution could be accomplished by readdition of the sodium chloride released polypeptides to the depleted preparations using a low salt buffer (section 2.6.). The reactivation was completely dependent on the addition of the $M_{r} 23,000$ polypeptide and the stimulation of oxygen evolution observed was approximately 400 and $800 \%$ using depleted inside-out vesicles and the Triton X-100 preparation, respectively (Tables I and II). Based on the initial rates, the reconstituted rates were 65 and $54 \%$, respectively. Addition of $\mathrm{Mn}^{2+}$ or the $\mathrm{M}_{r}$ 32,000 and 13,500 polypeptides in combination or individually resulted in no reactivation. Simultaneous addition of all three polypeptides caused a slightly higher extent of reconstitution. The reconstituted rate of oxygen evolution was completely sensitive to 3-(3,4-dichlorophenyl)1,1-dimethylurea (DCMU).

All three polypeptides could be rebound to both types of photosystem II preparations (Figure 7). Based on amino acid analysis of the purified polypeptides, the molecular weights ob- 


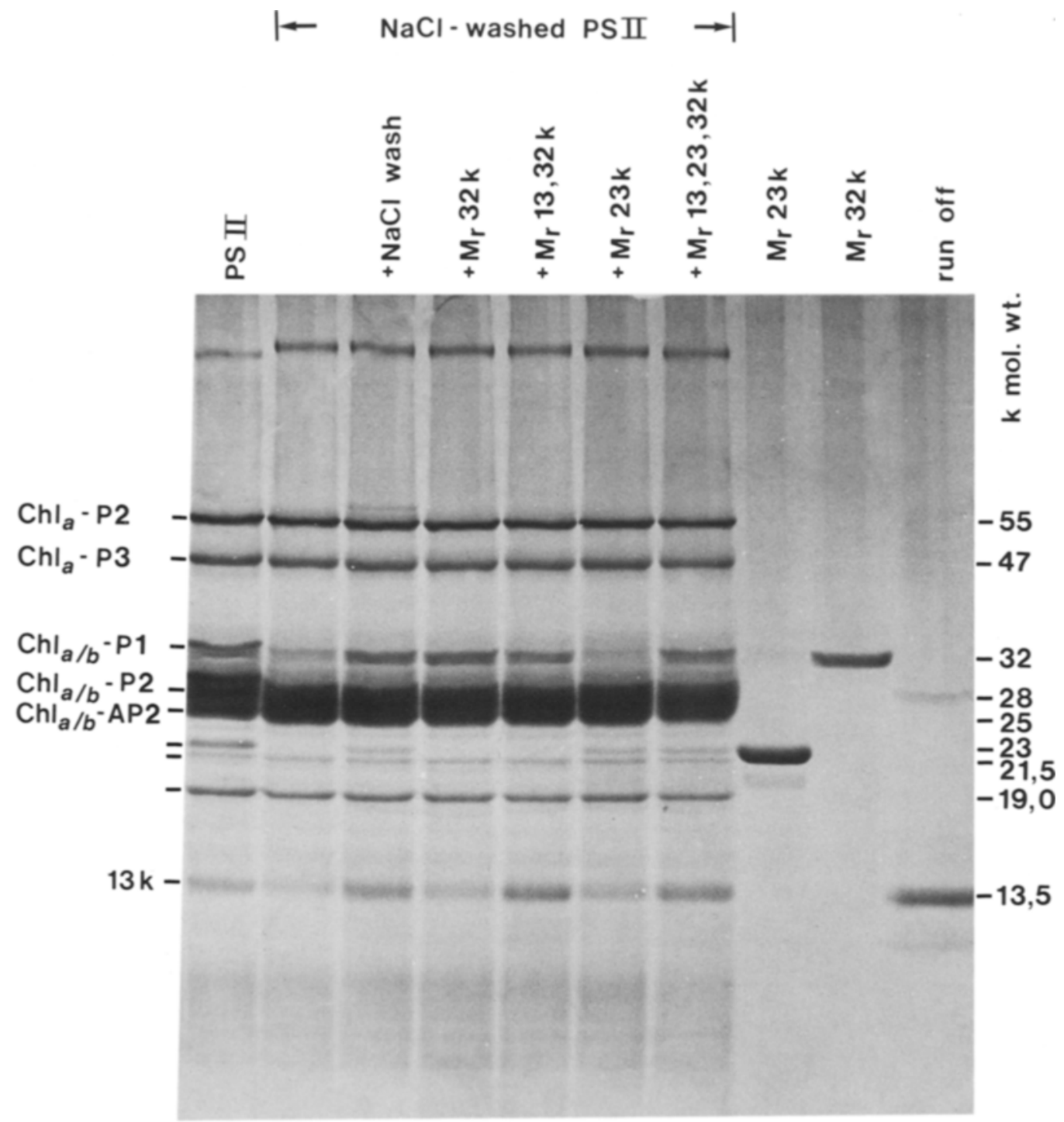

\section{$\begin{array}{lllllllllll}\text { A } & \text { B } & \text { C } & \text { D } & \text { E } & F & G & \text { H } & \text { I } & \text { J }\end{array}$}

Figure 7. Rebinding of polypeptides to photosystem II membranes inactivated by sodium chloride washing.

A: photosystem II membranes prepared with Triton X-100. B: "A" after washing with $200 \mathrm{~mm}-\mathrm{NaCl} / 10 \mathrm{~mm}$ Hepes $\mathrm{pH}$ 8.3. C: " $B$ " after rebinding of the polypeptides released by sonication. $D$ : " $B$ " after rebinding of the $M_{r}$ 32,000 polypeptide. E: "B" after rebinding of the $M_{r} 13,500$ and 32,000 polypeptides. F:" $B$ " after rebinding of the $M_{r}$ 23,000 polypeptide. $G$ : "B" after rebinding of the $M_{r} 13,500,23,000$, and 32,000 polypeptides. $H$ : purified $M_{r}$ 32,000 polypeptide. I: purified $M_{r} 23,000$ polypeptide. $J: M_{r} 13,500$ polypeptide as obtained from the run-off fraction from the chromatofocusing column.

served on SDS-PAGE, and a chlorophyll/P680 ratio of 320 , the polypeptides used for the reconstitution experiments were added in approximately a three molar excess over $P 680$. Addition of bovine serum albumin at a molar excess of 10 gave no binding of this protein to the depleted membranes. In contrast, the $\mathrm{M}_{\mathrm{r}} 20.000$ transformation product of the $M_{r} 23,000$ polypeptide 


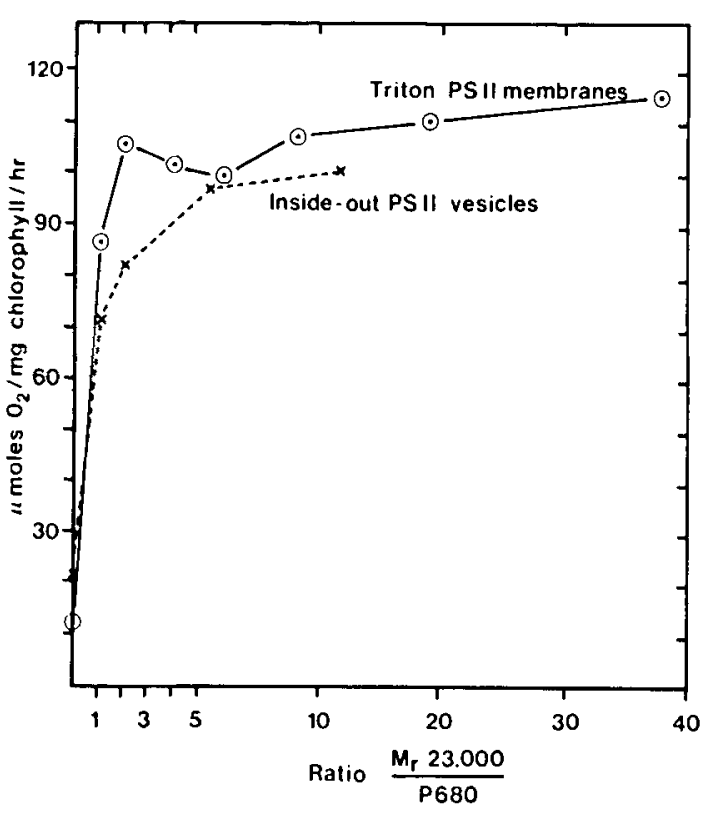

Figure 8. Reactivation of DCMU sensitive oxygen evolution in dependence of the amount of added $M_{r}$ 23,000 polypeptide.

Photosystem II membranes prepared with Triton $\mathrm{X}-100$ (6) and inside-out photosystem II vesicles were washed with $200 \mathrm{~mm}-\mathrm{NaCl} / 10 \mathrm{~mm}$-Hepes $\mathrm{pH} 8.3$. After pelleting, different amounts of $M_{r} 23,000$ polypeptide were added to produce the indicated molar ratios of $M_{r} 23,000$ polypeptide to $P 680$. After incubation, the reaction mixture was diluted with low salt buffer and the membranes pelleted before assaying in the oxygen electrode.

did bind (Figure 9), but this did not reactivate oxygen evolution even when added in a molar excess of 28.

High affinity of the $M_{r} 23,000$ polypeptide for the depleted photosystem II preparations was shown by measuring the extent of reactivation of oxygen evolution as a function of the relative amount of added $M_{r} 23,000$ polypeptide. The inside-out photosystem II vesicles and the Triton $\mathrm{X}-100$ photosystem II preparation again behaved almost identical (Figure 8). At a ratio between added $\mathrm{M}_{\mathrm{r}} 23,000$ polypeptide and $P 680$ of one, about $80 \%$ of the total reactivatable oxygen evolution was achieved. Considering the strong dilution of the membranes with low salt buffer, this experiment indicates an extremely high affinity between the $M_{r} 23,000$ polypeptide and the depleted membranes. At a ratio of four, the amount of $M_{r} 23,000$ polypeptide rebound to the depleted membranes appeared similar to the amount originally present (Figure 9). At drastically increased ratios, a slow increase in the amount of bound polypeptide was observed. This indicates that two types of binding sites differing in their affinity for the $\mathrm{M}_{\mathrm{r}}$ 23,000 polypeptide are present in the depleted vesicles. Only binding to the high affinity site reconstitutes oxygen evolution.

The fluorescence induction curves of the Triton X-100 photosystem II preparation were markedly influenced by the presence or absence of the $M_{r}$ 23,000 polypeptide (Figure 10). Upon salt washing, the variable fluorescence was reduced and the rise time increased. After rebinding of the $M_{r} 23,000$ polypeptide, the variable fluorescence was recovered and the rise time decreased. These alterations in the fluorescence induction curves are indicative of a block of the oxidizing side of photosystem II as shown using inhibitors (51) and mutants (5,7) and thus points towards the localization of the $M_{r} 23,000$ polypeptide on the oxidizing side of photosystem II.

Salt washing of normal thylakoids or of rightside out vesicles prepared by phase partitioning (55) does not inhibit oxygen evolution to any significant extent. The sensitivity of the Triton $\mathrm{X}-100$ preparation towards $\mathrm{NaCl}$ washing and the ability to rebind the $M_{\mathrm{r}} 23,000$ polypeptide thereby reactivating oxygen evolution agrees with the notion (section 3.2.) that this preparation is composed of pairs of appressed membrane sheets with their original luminal sides exposed towards the medium. If not sealed these membrane sheets would be expected to separate under the low salt conditions used for rebinding of polypeptides. In order to check this, a Triton $\mathrm{X}-100$ photosystem II preparation was resuspended in 25 mM-Hepes pH 7.5, embedded and sectioned. The electron micrographs (Figure 11) revealed that under these low salt conditions, the appressed inside-out membranes now were separated from one another over larger areas than at the high salt conditions. However, a considerable portion of the membrane sheets were still closely appressed. Such a separation of inside-out appressed sheets by removal of magnesium ions has also been observed with digitonin preparations (14). 


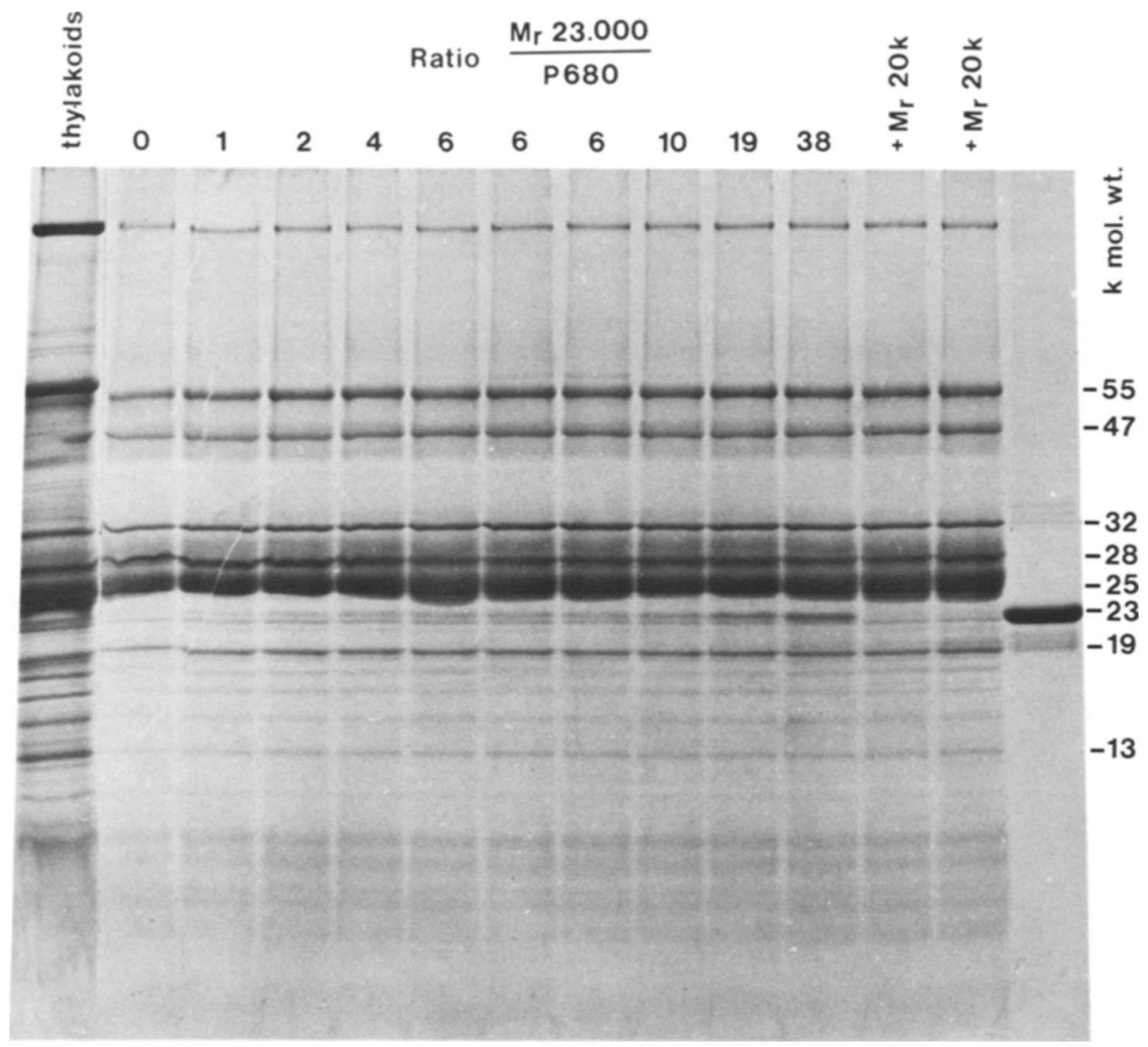

Figure 9. Rebinding of the purified $M_{r} 23,000$ polypeptide to depleted photosystem II membranes.

Depleted photosystem II membranes prepared with Triton X-100 were incubated with different amounts of $\mathrm{M}_{\mathrm{r}}$ 23,000 polypeptide to produce the $M_{r} 23,000 / P 680$ ratios indicated. After incubation, the reaction mixture was diluted with low salt buffer and the membranes pelleted before SDS-PAGE. In the second and third experiments with an $M_{r} 23,000 / P 680$ ratio of 6 , increasing amounts of the $M_{r} 32,000$ polypeptide were added. Binding experiments with the $M_{r} 20,000$ polypeptide were carried out using molar ratios of 10 and 28 , respectively. Electrophoretic conditions as in legend to Figure 3.

\subsection{Characteristics of the polypeptides released from the luminal side of the thylakoids by sodium chloride}

The method used for the release and isolation of polypeptides localized on the luminal side of the thylakoid membrane is fast and gentle avoiding any use of detergents and organic solvent extractions. Tris, which is known to inhibit oxygen evolution at alkaline pH $(13,19)$ was also excluded. Retention of any manganese originally bound to one of the isolated polypeptides would thus be favored. The destacked thylakoids contained 5.6 manganese atoms per $P 680$ reaction center assuming a chlorophyll/ $P 680$ ratio of 500 in the thylakoids. After the initial wash with the high salt buffer the number decreased to 5.1. Fol- 


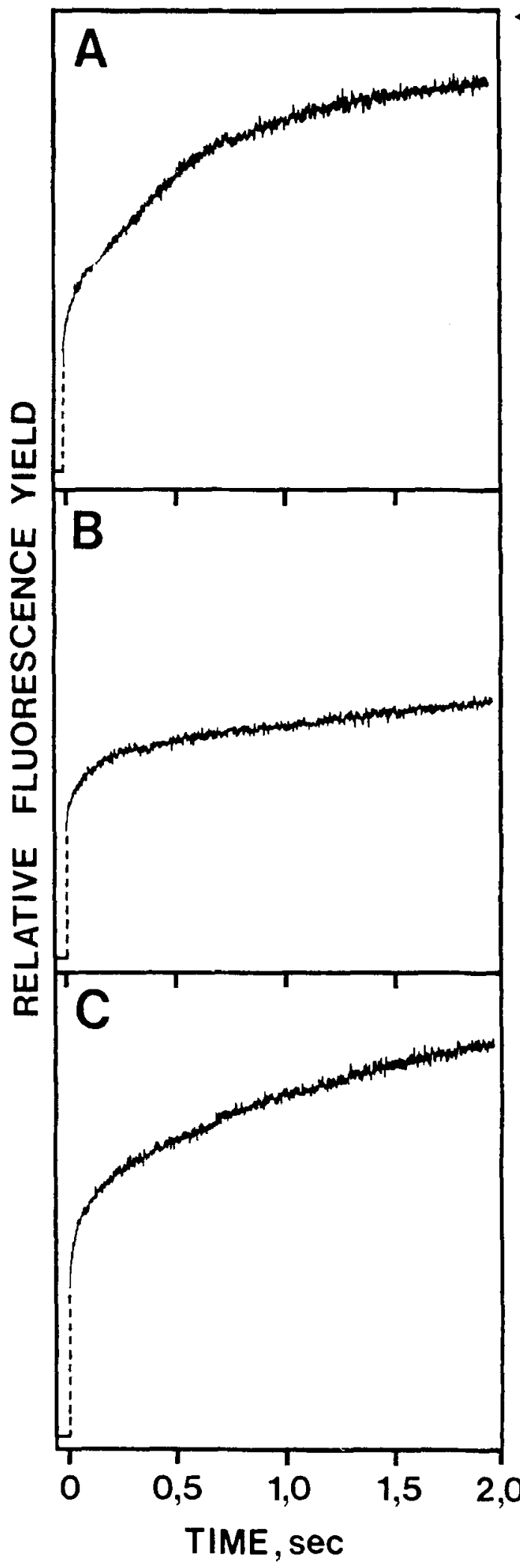

Figure 10. Fluorescence induction curves for photosystem II membranes prepared with Triton X-100 (A), after salt-washing (B) and after rebinding of the $\mathrm{M}_{\mathrm{r}}$ 23,000 polypeptide (C).

lowing sonication in the high salt buffer, the manganese content of the pelleted membranes had dropped to 3.3 per $P 680$ reaction center. The manganese released into the supernatant was lost by pressure filtration on a PM 10 filter and no manganese was associated with any of the polypeptides isolated. Preliminary data by AKERLUND et al. (55) indicated that no manganese was associated with the $\mathrm{M}_{\mathrm{r}} 23,000$ polypeptide obtained as a water soluble protein from acetone powders of thylakoids. The manganese still retained in the sonicated thylakoid membranes could be essential for reconstitution. The manganese removed may have a function in binding one or more of the released polypeptides to the membrane or in binding these polypeptides together. With the conditions used in the present study, the three polypeptides behaved as separate polypeptides not forming an aggregate. Thus gel filtration on Sephacryl S-200 equilibrated in $200 \mathrm{~mm}-\mathrm{NaCl} / 10 \mathrm{~mm}-\mathrm{Hepes}$ at $\mathrm{pH} 7.0$ produced three peaks representing the $M_{r}$ $32,000,20,000$ and 13,500 polypeptides in the expected order of elution. Gelfiltration was not attempted at low salt concentrations which was noted (section 3.1) to favor precipitation of the three polypeptides. Electrophoresis of the $\mathrm{M}_{\mathrm{r}}$ 32,000 and 23,000 polypeptides individually or in combination using non-denaturing conditions failed to demonstrate aggregation.

The amino acid compositions of the purified polypeptides is presented in Table III. The $M_{r}$ $13,500,23,000$ and 32,000 polypeptides all have polarity indexes between 46 and $48 \%$ and can therefore be classified as extrinsic or periferal membrane proteins not penetrating into the lipid bilayer (8). Several treatments are known to cause the release of polypeptides in the $\mathrm{M}_{\mathrm{r}}$

Figure 11. Electron micrographs of the photosystem II membranes prepared with Triton X-100 after resuspension in a low salt buffer.

The arrows indicate pairs of unsealed appressed membrane sheets which in the low salt buffer ( $25 \mathrm{~mm}$ Hepes $\mathrm{pH} 7.5$ ) have now separated over larger areas. 


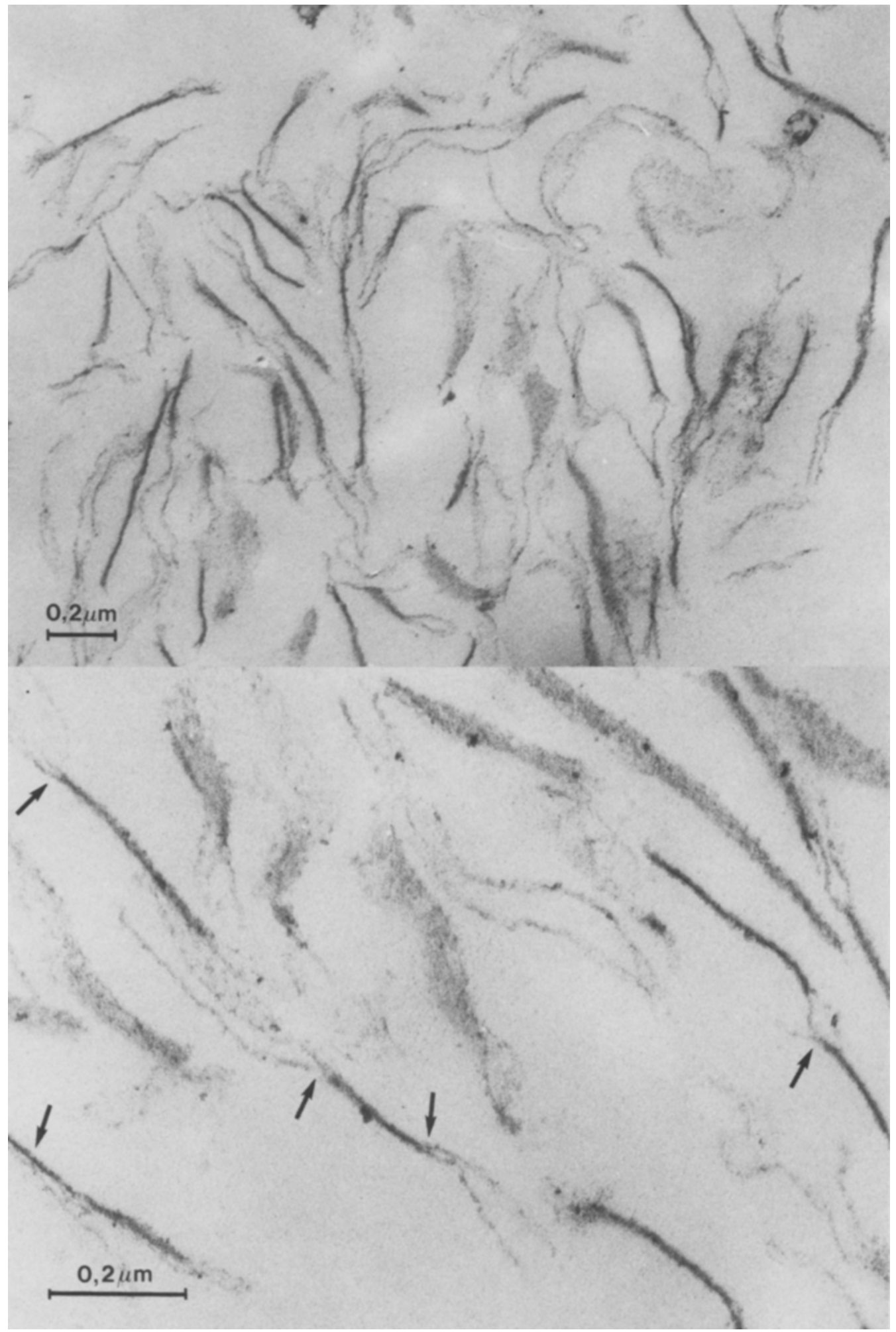


32,000 and 23,000 region. The use of $200 \mathrm{~mm}$ $\mathrm{NaCl} / 50$ mм-Tris at $\mathrm{pH} 8.3$ (Figure $3 \mathrm{C}$ ) released polypeptides with mobilities identical to those obtained by washing with $200 \mathrm{~mm}-\mathrm{NaCl} / 10 \mathrm{~mm}$ Hepes at pH 8.3. Similarly, washing of an enriched photosystem II preparation obtained with Triton X-100 at alkaline $\mathrm{pH}$ using Tris or Tricine buffer caused the release of polypeptides at $\mathrm{M}_{\mathrm{r}}$ $32.000,24,000$ and $15,000(30)$. The characteristics available and the possible identity of the polypeptides released by the various treatments are discussed in the following sections. The effect of salt on the extraction efficiency indicates that electrostatic forces are important in binding the polypeptides to the membrane. The facilitated release of the polypeptides at higher $\mathrm{pH}$ values are supposedly due to titration of charged amino groups involved in the electrostatic binding. A binding by electrostatic forces would be in agreement with the high polarity indices. Attempts to sequence the $M_{r} 32,000$ and 23,000 polypeptides from their amino terminal end by automatic EDMAN degradation were unsuccessful, indicating that both polypeptides have blocked $\mathrm{N}$-terminal amino acids. This may be important in the anchoring of these polypeptides to the thylakoid membrane.

\subsection{Characteristics and function of the isolated $M_{r}$ 32,000 polypeptide}

Electrophoresis of the $M_{r} 32,000$ polypeptide under denaturing and non-denaturing conditions showed that this protein had been purified to homogeneity (Figures 3,6 and 7). The amino acid composition of the isolated protein is very similar to that of a $M_{r} 32,000$ polypeptide removed from inside-out vesicles of spinach by washing with Tris $(19,50$, Møller and Henry, unpublished) and to that of $\mathrm{M}_{\mathrm{r}} 32,000$ polypeptide obtained from spinach by acetone extraction (29) (Table III). The pI of the isolated $M_{r}$ 23,000 polypeptide was 5.1 (section 3.6.). The $\mathrm{M}_{\mathrm{r}} 32,000$ polypeptide elutes $0.2 \mathrm{pH}$ units above the $M_{r}$ 23,000 polypeptide during chromatofocusing. The isoelectric point of the $M_{r}$ 32,000 polypeptide is therefore close to 5.3 . This value compares well with the $\mathrm{pI}$ values of 5.2 and 5.1 found for the $M_{r} 32,000$ polypeptides isolated from spinach $(29,50)$ altogether indicating that the same $M_{r} 32,000$ polypeptide is obtained by the three different isolation procedures.

Several properties have been assigned to polypeptides migrating in the $M_{r} 32,000$ region of the thylakoid pattern, but it remains unknown how many different polypeptides are responsible for these functions. Two lines of evidence suggest that the $M_{r} 32,000$ polypeptide isolated in this study is involved in the binding of manganese. Thus the specific release of the $M_{r} 32,000$ polypeptide upon washing of inside-out photosystem II vesicles with 50 or $200 \mathrm{~mm}$-Tris at $\mathrm{pH} 8.3$ was followed by a simultaneous loss of $70 \%$ of the membrane bound manganese (19). These washed inside-out vesicles were inactive with respect to oxygen evolution but could be reactivated with reduced 2,6-dichlorophenol indophenol (DCPIP) (19). In the present study, reactivation of photosystem II membranes depleted in the $\mathrm{M}_{\mathrm{r}}$ $13,500,23,000$ and 32,000 polypeptides by washing with $200 \mathrm{~mm}-\mathrm{NaCl} / 10 \mathrm{~mm}-\mathrm{Hepes}$ at $\mathrm{pH}$ 8.3 , could be accomplished solely by rebinding of the $M_{r}$ 23,000 polypeptide with no supplement of externally added manganese or DCPIP. These observations indicate that Tris washing has an additional effect on the thylakoid membrane besides that of removing the $M_{r} 32,000$ polypeptide. Analysis by polyacrylamide gel electrophoresis indicate that none of the two washing procedures completely removed the Coomassie Blue stained band at $M_{r} 32,000$ (Figure 6,7 and 9). Thus a quantitative determination of the amounts of $M_{r} 32,000$ polypeptide released by the two different procedures becomes difficult. If both washing procedures result in a complete removal of the $\mathrm{M}_{\mathrm{r}} 32,000$ polypeptide isolated in the present study, it can be concluded that this polypeptide is not essential for photosynthetical electron transfer from water. However, the maximal reconstitution observed in the two types of reactivation studies were remarkably similar and in the range of 60 to $70 \%$. This reactivation may be dependent on residual amounts of the $\mathrm{M}_{\mathrm{r}} 32,000$ polypeptide left on the membranes and indicate that although the isolated $M_{r} 32,000$ polypeptide can be rebound to the depleted membranes, the rebound polypeptide is not photochemically active, preventing a $100 \%$ reactivation of the membranes.

The second line of evidence for the involve- 
Table III.

Comparison of amino acid compositions of purified barley and spinach thylakoid polypeptides.

\begin{tabular}{|c|c|c|c|c|c|c|}
\hline \multirow[t]{2}{*}{ Species: } & \multicolumn{2}{|c|}{$\begin{array}{l}\mathrm{M}_{\mathrm{r}} 32,000 \\
\text { Barley } \\
\quad \text { moles } 2) \\
\end{array}$} & \multicolumn{2}{|c|}{$\begin{array}{c}\mathrm{M}_{\mathrm{r}} 23,000 \\
\text { Barley }\end{array}$} & \multirow{2}{*}{$\begin{array}{c}\mathrm{M}_{\mathrm{r}} 13,500 \\
\text { Barley } \\
\text { mole } \% \\
\end{array}$} & \multirow{2}{*}{$\begin{array}{r}\mathbf{M}_{\mathrm{r}} 11,50 \\
\text { Barley } \\
\text { mole\% }\end{array}$} \\
\hline & mole\%1) & mole $M_{r} 32,000$ & mole\% & mole $\mathrm{M}_{\mathrm{r}} 23,000$ & & \\
\hline As $x$ & 8,5 & 25 & 10.3 & 21 & 10.8 & 10.2 \\
\hline Thr & 8.2 & 24 & 7.1 & 15 & 6.2 & 6.0 \\
\hline Ser & 6.4 & 19 & 6.7 & 14 & 3.9 & 4.7 \\
\hline Glx & 11.9 & 32 & 10.3 & 21 & 7.6 & 8.6 \\
\hline Pro & 6.1 & 18 & 3.4 & 7 & 8.3 & 6.1 \\
\hline Gly & 10.9 & 32 & 10.7 & 22 & 6.8 & 5.7 \\
\hline Ala & 6.8 & 20 & 10.4 & 21 & 9.2 & 8.4 \\
\hline Val & 6.1 & 18 & 6.8 & 14 & 4.4 & 4.3 \\
\hline Met & 1.8 & 5 & 0.9 & 2 & 0.2 & 0.2 \\
\hline Ile & 3.6 & 10 & 3.3 & 7 & 4.2 & 5.4 \\
\hline Leu & 8.2 & 24 & 6.3 & 13 & 14.4 & 14.5 \\
\hline Tyr & 3.4 & 10 & 4.1 & 9 & 3.9 & 4.5 \\
\hline Phe & 6.2 & 18 & 6.1 & 13 & 2.3 & 2.7 \\
\hline His & 1.0 & 3 & 1.5 & 3 & 1.6 & 1.0 \\
\hline Lys & 8.3 & 24 & 9.0 & 18 & 11.0 & 13.2 \\
\hline Arg & 2.9 & 9 & 2.4 & 5 & 4.7 & 3.9 \\
\hline Cys & n.d. & - & n.d. & - & n.d. & n.d. \\
\hline Trp & n.d. & - & n.d. & - & n.d. & n.d. \\
\hline \multicolumn{2}{|c|}{ Total amino acids } & 294 & & 205 & & \\
\hline \multicolumn{2}{|c|}{ Polarity index (8) } & $48 \%$ & & $47 \%$ & $46 \%$ & $48 \%$ \\
\hline \multirow[t]{2}{*}{ Species: } & & $\begin{array}{c}\left.\mathrm{M}_{\mathrm{r}} 32,000^{4}\right) \\
\text { Spinach } \\
\text { moles }\end{array}$ & $\begin{array}{c}\left.\mathrm{M}_{\mathrm{r}^{3}} 32,0005\right) \\
\text { Spinach }\end{array}$ & \multicolumn{2}{|c|}{$\begin{array}{c}\left.\mathrm{M}_{\mathrm{r}} 24,0005\right) \\
\text { Spinach }\end{array}$} & $\begin{array}{c}\left.\mathbf{M}_{\mathbf{r}} 18,0005\right) \\
\text { Spinach }\end{array}$ \\
\hline & & le of $\mathrm{M}_{\mathrm{r}} 33,000$ & mole $\%$ & \multicolumn{2}{|c|}{ mole $\%$} & mole\% \\
\hline Asx & & 26 & 9.25 & \multicolumn{2}{|c|}{9.41} & 9.75 \\
\hline Thr & & 24 & 6.60 & \multicolumn{2}{|c|}{4.84} & 4.90 \\
\hline Ser & & 24 & 7.35 & \multicolumn{2}{|c|}{7.19} & 8.73 \\
\hline Glx & & 36 & 11.64 & \multicolumn{2}{|c|}{8.70} & 10.78 \\
\hline Pro & & 18 & 7.12 & \multicolumn{2}{|c|}{8.3} & 8.99 \\
\hline Gly & & 36 & 10.65 & \multicolumn{2}{|c|}{9.3} & 6.53 \\
\hline Ala & & 20 & 6.14 & \multicolumn{2}{|c|}{7.08} & 8.69 \\
\hline Val & & 23 & 6.92 & \multicolumn{2}{|c|}{6.62} & 4.28 \\
\hline Met & & 1 & 0.69 & \multicolumn{2}{|c|}{ trace } & trace \\
\hline Ile & & 10 & 3.28 & \multicolumn{2}{|c|}{3.43} & 4.21 \\
\hline Leu & & 21 & 7.09 & \multicolumn{2}{|c|}{5.89} & 10.18 \\
\hline Tyr & & 10 & 3.32 & & & 2.85 \\
\hline Phe & & 16 & 4.89 & & & 2.18 \\
\hline His & & 0 & trace & $\operatorname{tra}$ & & trace \\
\hline Lys & & 29 & 9.14 & & & 9.01 \\
\hline Arg & & 9 & 2.75 & & & 4.85 \\
\hline Cys & & 2 & trace & $\operatorname{tra}$ & & trace \\
\hline $\begin{array}{l}\text { 1) } 24 \text { hour } \\
\text { 2) Based o } \\
\text { 3) Based o }\end{array}$ & $\begin{array}{l}\text { Arolysis. Ur } \\
\text { residues of } \\
\text { residues of }\end{array}$ & $\begin{array}{l}\text { leucine per molec } \\
\text { leucine per molec }\end{array}$ & threonine a & & $\begin{array}{l}\text { 4) From (29) } \\
\text { 5) From (50) } \\
\text { n.d. = not de }\end{array}$ & rmined. \\
\hline
\end{tabular}


ment of an $\mathrm{M}_{\mathrm{r}} 32,000$ polypeptide in the binding of manganese was obtained using Scenedesmus mutants specifically blocked on the oxidizing side of photosystem II $(35,36)$. It was demonstrated that these mutants, which lack oxygen evolving capacity, but retain an otherwise functional photosystem II reaction center, are affected in their capacity for binding manganese. The only difference observed upon denaturing PAGE was a change in electrophoretic mobility of a $M_{r} 34,000$ polypeptide present in the wild type to an $M_{r} 36,000$ in the mutants. It was suggested that the $M_{r} 36,000$ band represents an inactive precursor form of the manganese binding $M_{r} 34,000$ polypeptide $(35,36)$, and that the $M_{r}$ 34,000 polypeptide is associated with the manganese requiring portion of the water splitting enzymes. These properties indicate that the $M_{r}$ 34,000 polypeptide lacking in the mutants could be identical to that isolated in the present study and that the manganese originally bound to the protein was irreversibly lost during extraction which explains why no additional reactivation was observed upon rebinding the protein to the depleted membranes.

Analysis of the chlorophyll-protein composition of the photosystem II preparation used in this study reveals the presence of both chlorophyll $a / b$ proteins 1 and 2 . Chlorophyll $a / b$ protein I comigrates with the isolated $M_{r} 32,000$ polypeptide $(19,21)$. However, the absence of chlorophyll $a / b$ protein 1 in the photosynthetically competent barley mutant chlorina $f 2(31)$ suggests that this is a different protein. An $M_{r} 32,000$ polypeptide has also been implicated on the reducing side of photosystem II and identified as the protein which binds DCMU and atrazin $(34,39)$. The nucleotide sequence of the gene coding for this $M_{r} 32,000$ polypeptide is known for spinach and tobacco and an absolute conservation of the amino sequence was found (52). The protein contains no lysine and is thus clearly different from the $\mathrm{M}_{\mathrm{r}} 32,000$ polypeptide isolated in this study (Table III). Further the DCMU-binding protein does not appear to stain with Coomassie Blue $(33,52)$.

Cytochrome $b-559$ is also present in the photosystem II preparations. Electrophoretic analysis of isolated cytochrome $b-559$ revealed the presence of a Coomassie Blue staining band at $\mathrm{M}_{\mathrm{r}}$
9,300. Bands staining with 3,3',5,5'-tetramethyl benzidine (TMBZ) but not staining with Coomassie Blue were observed at $\mathrm{M}_{\mathrm{r}} 32,000$ and 31,000 (28). The here isolated $M_{r} 32,000$ polypeptide did not stain with TMBZ. Solubilization of cytochrome $b-559$ under mild conditions resulted in its isolation together with components of $\mathrm{M}_{\mathrm{r}} 32,000$ and 21,000 which were suggested to be identical to those released by salt washing of inside-out vesicles. A comparison of the gel profiles in (28, Figure 7) with those here obtained (Figure 6) reveals that the polypeptides indeed have identical mobilities and points towards an in vivo association of cytochrome $b-559$ with the isolated $\mathrm{M}_{\mathrm{r}}$ 23,000 and 32,000 polypeptides.

\subsection{Characteristics and function of the isolated $M_{r}$ 23,000 polypeptide}

The purity of the isolated $M_{r}$ 23,000 polypeptide was analyzed by denaturing and non-denaturing polyacrylamide gel electrophoresis and by isoelectric focusing. In all three systems a single Coomassie Blue band was obtained. A possible micro-heterogeneity of the isolated $M_{r}$ 23,000 polypeptide with respect to the amount of bound lipids and sugars would most likely have resulted in the presence of multiple bands upon isoelectric focusing. The protein did not stain with TMBZ. Boiling of the $\mathrm{M}_{\mathrm{r}} 23,000$ protein in the presence of oxidizing or reducing agents did not change it to the $M_{r} 20,000$ form, indicating that the transition observed after Tristreatment and gel filtration (Figure 3, lanes C, D, $\mathrm{H})$ does not result from the presence of labile intra-chain sulfhydryl groups. The amino acid analysis indicate that the $M_{r}$ 23,000 polypeptide is hydrophilic as is also apparent from its solubility in water in the absence of detergents. When highly concentrated the $M_{r} 23,000$ polypeptide remains colorless. The absorption spectrum of the $M_{r} 23,000$ polypeptide revealed no special characteristics and no cofactors could be detected from its reduced (dithionite) minus oxidized (persulphate) difference spectrum:

YAMAMOTO et al. (50) reported on the purification of a Tris-releaseable polypeptide of $\mathrm{M}_{\mathrm{r}}$ 24,000 . This protein was not tested for its ability to reconstitute oxygen evolution in depleted membranes. The $\mathrm{pI}$ of this protein was 6.5 whereas the $\mathrm{pI}$ of the here isolated $\mathrm{M}_{\mathrm{r}} 23,000$ 
polypeptide is 5.1 . The amino acid composition of the two proteins also differ significantly (Table III). Based on the isoelectric focusing profiles published in (50) we conclude that the discrepancies arise from the analysis of an only partly purified $M_{r} 24,000$ polypeptide.

Apart from the conditions under which the $M_{r}$ 23,000 polypeptide is converted into the $M_{r}$ 20,000 species (section 3.1.) it is remarkable stable. Heating for five minutes at $55^{\circ} \mathrm{C}$ or $98^{\circ} \mathrm{C}$ followed by immediate transfer to ice resulted in a 20 and $35 \%$ decrease, respectively, in its ability to reconstitute oxygen evolution under standard assay conditions. Storage of the purified $\mathrm{M}_{\mathrm{r}}$ 23,000 polypeptide for several weeks at $-80^{\circ} \mathrm{C}$ in Polybuffer 74 at pH 4.8 and without addition of reducing agents causes no detectable loss of its reconstituting activity.

The remarkable heat stability observed could indicate that a non-proteinaceous component present in the $M_{r}$ 23,000 preparation mediated the observed reactivation. We exclude this possibility for the following three reasons: There is a distinct dependence between the amount of added $M_{r}$ 23,000 polypeptide and the reactivation observed (Figure 8). The $M_{r} 20,000$ conversion product does not mediate this reactivation. The $M_{r}$ 23,000 polypeptide elutes as a rather sharp peak from the chromatofocusing column (Figure 1) and no reconstitution was observed with adjacent fractions. A contaminating polypeptide not staining with Coomassie Blue can only be present in the preparation if it co-elutes excactly with the $\mathrm{M}_{\mathrm{r}}$ 23,000 polypeptide during chromatofocusing because the staining intensity of the individual fractions parallel the symmetrical $280 \mathrm{~nm}$ absorption peak in which the $\mathrm{M}_{\mathrm{r}} 23,000$ polypeptide elute. A contaminant present in significant amounts would have been detected upon the attempted EDMAN degradation of the $M_{r}$ 23,000 polypeptide, unless this contaminant also had a blocked N-terminal.

In contrast to the situation with the $\mathrm{M}_{\mathrm{r}} 32,000$ polypeptide band in thylakoid SDS-PAGE patterns, the Coomassie Blue staining band at $\mathrm{M}_{\mathrm{r}}$ 23,000 seems to reflect the presence of only one polypeptide. Under the conditions used here, washing of both thylakoids and the photosystem II preparations with $200 \mathrm{~mm}-\mathrm{NaCl} / 10 \mathrm{~mm}$ Hepes at $\mathrm{pH} 8.3$ completely removes the
Coomassie Blue stained band at the $M_{r} 23,000$ position (Figures 6 and 7).

The mechanism by which the $\mathrm{M}_{\mathrm{r}} 23,000$ polypeptide mediates the reconstitution of photosynthetic oxygen evolution in depleted membranes is still not elucidated. The oxygen evolving enzyme system is considered to be highly sensitive towards heat treatment (26). Whereas the $M_{r}$ 23,000 polypeptide was found to be heat stable, the depleted membranes are heat Jabile. A five minute heat treatment of the membranes at $55^{\circ} \mathrm{C}$ prevented any reconstitution with unheated $M_{r}$ 23,000 polypeptide. Similarly the oxygen evolving system is easily destroyed by hydroxylamine treatment, particularly in the $S_{0}$ state (9). The high affinity of the oxygen evolving site towards hydroxylamine was recently demonstrated directly by mass spectrometric analysis of the yields of $\mathrm{N}_{2}$ and $\mathrm{O}_{2}$ obtained upon subjecting thylakoids to saturating flashes in the presence of very low hydroxylamine concentrations $(10 \mu \mathrm{M}$ hydroxylamine in $55 \mathrm{M}-\mathrm{H}_{2} \mathrm{O}$ ) (40). Washing of depleted photosystem II membranes with $1 \mathrm{~mm}$ hydroxylamine prevents any subsequent reactivation with untreated $M_{r} 23,000$ polypeptide. The sensitivity of the depleted membranes towards both heat and hydroxylamine treatment suggest that a component of the oxygen evolving enzyme system is retained on the membranes after removal of the $M_{r} 23,000$ polypeptide.

EPR studies have provided evidence for the existence of an electron carrier $Z$ between the oxygen evolving site and $P 680$, and hydroxylamine also inhibits electron transfer between $\mathrm{Z}$ and $P 680$ (15). No electron carrier properties could be found with the isolated $M_{r} 23,000$ polypeptide. It is therefore most likely not a polypeptide binding the postulated electron carrier $Z$. Since oxygen evolution is inhibited by the removal of the $M_{r} 23,000$ polypeptide and reactivated by its rebinding we conclude that the $M_{r}$ 23,000 polypeptide is an essential part of the oxygen evolving complex to which no specific function can as yet be ascribed.

SPECTOR and WINGET reported on the isolation of a manganese-containing protein of $M_{r} 65,000$ involved in the reconstitution of oxygen evolution of depleted thylakoids (45). Although the results of this study could not be repeated (42, 43 ), it is interesting to note that an $M_{r} 23,000$ 
polypeptide constitutes a major component during the initial purification steps of the $M_{r} 65,000$ polypeptide. Its presence as a minor impurity in the preparation used for the rebinding experiments may have resulted in the reported reconstitution. In a subsequent report (43) the selective inactivation of oxygen evolution by cholateazolectin extraction of thylakoids was found to be inhibited by the inclusion of ethylene glycol. A comparison of the electrophoretic patterns of extracted thylakoids reveal that in the presence of ethylene glycol, the extraction of an $M_{r}$ 23,000 polypeptide is prevented. This is probably the reason for the observed protective effect of ethylene glycol. No polypeptide was found at $M_{r} 65,000$ in the photosystem II preparations used in this study. The sonication procedure used on whole lamellar systems released a polypeptide of approximately $\mathrm{M}_{\mathrm{r}} 58,000$ which could be identical to that released from insideout vesicles upon EDTA washing (32). We obtained no evidence to suggest that this polypeptide was involved in the reconstitution process.

\subsection{Characteristics and identification of the low molecular weight polypeptides separated by cation exchange chromatography}

As previously mentioned, the polypeptide of $M_{r} 13,500$ is one of the major components released upon sonication of thylakoids in the presence of $200 \mathrm{~mm}-\mathrm{NaCl} / 10 \mathrm{~mm}$-Hepes at $\mathrm{pH} 8.3$ (Figure 3). This major polypeptide and some minor components did not bind to the chromatofocusing column. Even after equilibration of the anionic Polybuffer exchanger at $\mathrm{pH} 9.0$ in $20 \mathrm{~mm}$-ethanolamine, these polypeptides did not bind. This indicate that their isoelectric points are above pH 9.0. Consequently, these polypeptides were fractionated by cation exchange chromatography on CM-Sepharose $\mathrm{Cl} 6 \mathrm{~B}$ (Figure 2). Besides of their high isoelectric points the polypeptides showed several similarities to histones: The total polypeptide pattern of the run-off from the chromatofocusing column and that of a total histone extract from barley (37) was similar. The separation in the $M_{r} 11,000-14,000$ region resembles that reported for the $F_{3}$ and $F_{2}$ histones of calf thymus $\left(M_{r} 11,000-14,000\right)(48)$. In vivo, these histones are modified by acetylation of lysine residues creating a population of proteins with identical amino acid composition but with different net charges. The degree of acetylation alters their binding strength on the cation exchanger and their electrophoretic mobilities. At higher degrees of acetylation of the protein both the salt concentration required for its elution and its mobility upon SDS-PAGE is lowered. With respect to the fractionated proteins on Figure 2, the amino acid composition of pooled fractions 33-35 and of pooled fractions 52-56 were found to be very similar if not identical (Table III). Although the amino acid composition of the $M_{r} 13,500$ polypeptide is not typical for a histone, it may be that the observed differences in the electrophoretic mobilities of the polypeptides in the region $M_{r} 11,000-14,000$ reflects various degrees of acetylation of a single polypeptide chain.

An $M_{r} 18,000$ polypeptide released from an active photosystem II preparation by Tris washing has been isolated and characterized by YAMAMOTO et al. (50). This polypeptide had a pl of 9.2. However, when the amino acid composition of this polypeptide was compared with that of the isolated $M_{r} 13,500$ and 11,500 polypeptides, significant differences in the threonine, serine, and leucine content was apparent (Table III). The ratio of basic (his+arg+lys) to acidic (glxtasx) residues is 0.95 and 0.96 in the $M_{r} 13,500$ and 11,500 polypeptides, respectively, whereas the ratio is 0.61 in the $M_{r} 18,000$ polypeptide (50). It is therefore unlikely that the $M_{r} 18,000$ polypeptide bears any relationship to the $M_{r}$ 13,500 and 11,500 polypeptides here isolated. ÁKERLUND et al. (53) purified an $\mathrm{M}_{\mathrm{r}} 16,000$ polypeptide as a water soluble protein from an acetone extract of spinach thylakoids. A polypeptide with the same mobility was released by salt washing of inside-out vesicles. This polypeptide did not bind to an anion exchange resin and is therefore also basic and possibly identical to the $M_{r} 18,000$ polypeptide of Yамамото et al. (50). ToYoshima and FuKUTAKA obtained an $\mathrm{M}_{\mathrm{r}}$ 17,000 polypeptide by cholate extraction of sonicated thylakoids (47). This polypeptide was able to stimulate oxygen evolution when added to extracted membranes but the overall rates were low. Again this protein does not bind to an anion exchange resin. For unknown reasons, we did not observe the release of a polypeptide in this 
region under any of the washing conditions tested although the photosystem II membranes used did contain a polypeptide of $M_{r} 19,000$. This polypeptide is probably the one which can be labelled with ${ }^{14} \mathrm{C}$-DCCD (24) and is intimately involved on the reducing side of photosystem II. A different candidate is the component sporadically appearing at $M_{\mathrm{r}} 20,000$ upon salt washing of inside-out vesicles (Figure 3, D). However, the release of this component by washing results in a reduced staining intensity in the $M_{r} 23,000$ region of the washed membranes and an unaltered staining intensity at $M_{r} 20,000$ and therefore probably does not represent a genuine component of the photosystem II membrane, but rather the modified or partially degraded $M_{r}$ 23,000 polypeptide (cf. section 3.1 .).

\section{ACKNOWLEDGEMENTS}

Professor D. vON WETTSTEIN is thanked for encouragement throughout the course of this work and for a careful review of the manuscript. We are grateful to INGA OLSEN for excellent technical assistance. Preben Bach Holm, Søren W. Rasmussen, Jean Sage and Bibi Stampe AnDERSEN are thanked for introducing us to the technique of electron microscopy. Iв SvEndSEN, Bodil Corneliussen and Lone Sørensen are thanked for carrying out amino acid analyses. Ole BORGGÅRD, Department of Agricultural Chemistry, Royal Veterinary and Agricultural University is thanked for performing the manganese determinations. AVRIL BAYNe and Nina RASMUSSEN are thanked for help with photographic work and figures. The little that is left, we did ourselves. This work was supported by the Commission of the European Communities contract no ESD-O13 DK of the Solar Energy Programme to D. von WeTtSTEIN and by a Niels Bohr stipend to B.L. Møl.LER.

\section{REFERENCES}

1. Albertsson, P.-A..: Separation of particles and macromolecules by phase-partitioning. Endeavour 1, 69-74 (1977)

2. Amesz, J.: The role of manganese in photosynthetic oxygen evolution. Biochim. Biophys.Acta. 726, 1-12 (1983)

3. Andersson, B., H.-E. Åkerlund \& P.-Ȧ. AL-
BERTSSON: Separation of subchloroplast membrane particles by counter-current distribution. Biochim. Biophys. Acta 423, 122-132 (1976)

4. ARnon, D.I.: Copper enzymes in isolated chloroplasts. Polyphenoloxidase in Beta vulgaris. Plant Physiol. 24, 1-14 (1949)

5. Bennoun, P., B.A. Diner, F.-A. Wollman, G. SChmidT \& N.-H. ChuA: Thylakoid polypeptides associated with photosystem II in Chlamydomonas reinhardtii: Comparison of system II mutants and particles. Photosynth., Proc. 5th Int. Congr. Volume 3, 839-849 (1981)

6. BERTHOLD, D.A., G.T. BABCOCK \& C.F. YOCUM: A highly resolved, oxygen-evolving photosystem II preparation from spinach thylakoid membranes. EPR and electron transport properties. FEBS Lett. 134, 231-234 (1981)

7. BISHOP, N.I. \& G. ÖQuisT: Correlation of the photosystem I and II reaction center chlorophyll-protein complexes, CP-a and $\mathrm{CP}-\mathrm{a}_{\mathrm{II}}$, with photosystem activity and low temperature fluorescence emission properties in mutants of Scenedesmus. Physiol. Plant. 49,477. 486 (1980)

8. Capaldi, R.A. \& G. Vanderkoor: The low polarity of many membrane proteins. Proc. Natl. Acad. Sci. USA 69, 930-932 (1972)

9. Cheniae, G.M. \& I.F. Martin: Effects of hydroxylamine on photosystem II. I. Factors affecting the decay of $\mathrm{O}_{2}$ evolution. Plant Physiol. 47, 568-575 (1971)

10. Cheniae, G.M. \& I.F. Martin: Studies on the mechanisms of Tris-induced inactivation of oxygen evolution. Biochim. Biophys. Acta. 502, 321-344 (1978)

11. Davis, B.J.: Disc electrophoresis II. Method and application to human serum proteins. Ann. N.Y. Acad. Sci. pp. 404-427 (1964)

12. Dismukes, C.G. \& Y. Siderer: Intermediates of a polynuclear manganese center involved in photosynthetic oxidation of water. Proc. Natl. Acad. Sci. USA 78, 274-278 (1981)

13. Frasch, W.D. \& G.M. Cheniae: Flash inactivation of oxygen evolution. Identification of $\mathrm{S}_{2}$ as the target of inactivation by Tris. Plant Physiol. 65, 735-745 (1980)

14. Gerola, P.D., F.M. Garlaschi, G. Forti \& R.C. JENNINGS: Effects of cations on the adhesion between membrane vesicles obtained by digitonin fractionation of spinach chloroplasts. Biochim. Biophys, Acta. 679,101-109 (1982)

15. Ghanotakis, D. \& G.T. Babcock: Hydroxylamine as an inhibitor between $\mathrm{Z}$ and $\mathrm{P} 680$ in photosystem II. FEBS Lett. 153, 231-234 (1983) 
16. GovinJeE \& R. GovinJeE: Introduction to photosynthesis. In: Bioenergetics of Photosynthesis, Govinjee ed., Academic Press pp. 150 (1975)

17. Hauska, G.A., R.E. McCarty, R.J. Berzborn \& E. RACKER: Partial resolution of the enzymes catalyzing photophosphorylation. VII. The function of plastocyanin and its interaction with a specific antibody. J. Biol Chem. 246, 3524-3531 (1971)

18. Henry, L.E.A., \& B.L. Møller: Polypeptide composition of an oxygen evolving photosystem II vesicle from spinach chloroplasts. Carlsberg Res. Commun. 46, 227-242 (1981)

19. Henry, L.E.A., B.L. Møller, B. Andersson \& H.-E. ÅKerLund: Reactivation of photosynthetic oxygen evolution in Tris-inactivated inside-out photosystem II vesicles from spinach. Carlsberg Res. Commun. 47, 187-198 (1982)

20. Henry, L.E.A., J.D. Mikkelsen \& B.L. Møller: Pigment and acyl lipid composition of photosystem I and II vesicles and of photosynthetic mutants in barley. Carlsberg Res. Commun. 48, 131-148 (1983)

21. Hiller, R.G., B.L. Møller \& G. HøyerHANSEN: Characterization of six putative photosystem I mutants in barley. Carlsberg Res. Commun. 45, 315-328 (1980)

22. Hind, H., Y. Nakatani \& S. Izawa: The role of $\mathrm{Cl}-$ in photosynthesis. I. The $\mathrm{Cl}^{-}$requirement of electron transport. Biochim. Biophys. Acta 172, 277-289, (1969)

23. Isoelectric focusing. Principles and Methods. Pharmacia Fine Chemicals, Uppsala, Sweden (1982)

24. Johanningmeier, U., P.V. Sane, G. HøyerHaNSEN \& B.L. Møller: The inhibition of photosynthetic electron flow by N,N'-dicyclohexyl-carbodiimide (DCCD). Photosynth., Proc. 5th Int. Congr. Vol. II, 247-258 (1981)

25. KahN, A. \& D. von WetTSTEIN: Macromolecular physiology of plastids. II. Structure of isolated spinach chloroplasts. J. Ultrastruct. Res. 5, 557-574 (1961)

26. Katoh, S. \& A. San Pietro: Ascorbate-supported NADP photoreduction by heated Euglena chloroplasts. Arch. Biochem. Biophys. $122,144-152$ (1967)

27. Katoh, S., I. Shiratori \& A. Takamiya: Purification and some properties of spinach plastocyanin. J. Biochem. 51, 32-40 (1962)

28. Koenig, F. \& B.L. Møller: Isolation and characterization of cytochrome $b-559$ from chloroplasts and etioplasts of barley. Carlsberg Res. Commun. 47, 245-262 (1982)

29. Kuwabara, T. \& N. Murata: An improved purification method and a further characterization of the 33-kilodalton protein of spinach chloroplasts. Biochim. Biophys. Acta 210-215 (1982)

30. Kuwabara, T. \& N. Murata: Inactivation of photosynthetic oxygen evolution and concomittant release of three polypeptides in the photosystem II particles of spinach chloroplasts. Plant Cell Physiol. 23, 533-539 (1982)

31. Machold, O., D.J. Simpson \& B.L. Møller: Chlorophyll-proteins of thylakoids from wildtype and mutants of barley (Hordeum vulgare L.). Carlsberg Res. Commun. 44, 235-254 (1979)

32. Mansfield, R.W.\& J. Barber: EDTA-induced release of manganese and proteins from insideout thylakoid vesicles and the inhibition of oxygen evolution. Biochem. Biophys. Res. Commun. 110, 545-551 (1983)

33. Mattoo, A.K., J.B. Marder, J. Gressel \& M. EDELMAN: Presence of the rapidly- labelled 32000-dalton chloroplast membrane protein in triazine resistant biotypes. FEBS Lett. 140, 3640 (1982)

34. Mattoo, A.K., U. Pick, H. Hoffman-Falk \& M. EDELMAN: The rapidly metabolized 32,000 dalton polypeptide of the chloroplast is the "proteinaceous shield" regulating photosystem II electron transport and mediating diuron herbicide sensitivity. Proc. Nat. Acad. Sci. USA 78, 1572-1576 (1981)

35. Metz, J. \& N.I. Bishop: Identification of a chloroplast membrane polypeptide associated with the oxidising side of photosystem II by the use of select low-fluorescent mutants of Scenedesmus. Biochem. Biophys. Res. Commun. 94, 560-566 (1980)

36. Metz, J.G., J. Wong \& N.I. BIShop: Changes in electrophoretic mobility of a chloroplast membrane polypeptide associated with the loss of the oxidizing side of photosystem II in low fluorescent mutants of Scenedesmus. FEBS Lett. $114,61-66(1980)$

37. Nadeau, P., D. Pallotta \& J.-G. Lafontaine: Electrophoretic study of plant histones: comparison with vertebrate histones. Arch. Biochem. Biophys. Acta 161, 171-177 (1974)

38. Nakatani, H. \& J. Barber: Cholate extraction of a heme-protein from spinach thylakoids and its possible involvement in PS II oxygen evolution. Photobiochem. Photobiophys. 2, 69-78 (1981) 
39. Pfister, K., K.E. Steinback, G. Gardner \& C.J. ARNTZEN: Photoaffinity labeling of an herbicide receptor protein in chloroplast membranes. Proc. Natl.Acad. Sci. USA 78,981-985 (1981)

40. RADMER, R. \& O. Ollinger: Nitrogen and oxygen evolution by hydroxylamine treated chloroplasts. FEBS Lett. 144, 162-166 (1982)

41. SAUER, K.: A role for $\mathrm{Mn}$ in $\mathrm{O}_{2}$ evolution in photosynthesis. Acc.Chem.Res. 13, 249-256 (1980)

42. SaYre, R. \& G. Cheniae: Thylakoid polypeptide composition and manganese binding and their relation to oxygen evolution. Photosynth., Proc. 5th Int.Congr. Volume 2, 473-485 (1981)

43. Sayre, R.T. \& G.M. Cheniae: Studies on the reconstitution of $\mathrm{O}_{2}$-evolution of chloroplasts. Plant Physiol. 69, 1084-1095 (1982)

44. Simpson, D.J. \& D. von Wettstein: Macromolecular physiology of plastids. XIV. Viridis mutants in barley: Genetic, fluoscopic, and ultrastructural characterization. Carlsberg Res. Commun. 45, 283-314 (1980)

45. Spector, M. \& G.D. Winget: Purification of a manganese containing protein involved in photosynthetic oxygen evolution and its use in reconstituting an active membrane. Proc.Natl.Acad. Sci. USA 77, 957-959 (1980)

46. Stewart, A.C. \& D.S. Bendall: Properties of oxygen-evolving photosystem II particles from Phormidium laminosum, a thermophilic bluegreen algae. Biochem.J. 194, 877-887 (1981)

47. Toyoshima, Y. \& E. Fukutaka: A protein essential for recovering oxygen evolution in cholate-treated chloroplasts. FEBS Lett. 150, 223227 (1982)

48. Wangh, L., A. Ruiz-Carrillo \& V.G. AllFREY: Separation and analysis of histone subfractions differing in their degree of acetylation: Some correlations with genetic activity in development. Arch.Biochem. Biophys. 150, 4456 (1972)
49. Wettstein, D.von, B.L. Møller, L.E.A. HenRY, F. Koenig, G. Høyer-Hansen \& C. PoulSEN: Polypeptides associated with the oxygen evolving system. In: Proc. E.C. Contractors Meeting, Brussels 1982, D.O.Hall \& W.Palz eds., Riedel Dordrecht, Boston/London, 148154 (1983)

50. Yamamoto, Y., S. Shimada \& M. Nishimura: Purification and molecular properties of three polypeptides released from a highly active $\mathrm{O}_{2}$ evolving photosystem-II preparation by Tristreatment. FEBS Lett. 151, 49-53 (1983)

51. Yamashita, T. \& W.L. Butler: Inhibition of the Hill reaction by Tris and restoration by electron donation to photosystem II. Plant Physiol. 44, 435-438 (1969)

52. Zurawski, G., H.J. Bohnert, P.R. Whitfield $\&$ W. Botтомley: Nucleotide sequence of the gene for the $M_{r}$ 32,000 thylakoid membrane protein from Spinacia oleracea and Nicotiana debneyi predicts a totally conserved primary translation product of $\mathrm{M}_{\mathrm{r}} 38,950$. Proc. Natl.Acad. Sci. USA 79, 7699-7703 (1982)

53. ÁkerLund, H.-E.; Partial reconstitution of the photosynthetic water splitting in inside out thylakoid vesicles. Photosynth., Proc. 5th Int.Congr. Vol. II, 465-472.

54. Åkerlund, H.-E., B. Andersson \& P.-Á. AlBERTSSON: Isolation of photosystem II enriched membrane vesicles from spinach chloroplasts by phase partitioning. Biochim. Biophys. Acta 449, 525-535 (1976)

55. Åkerlund, H.-E., C. Jansson \& B. AndersSON: Reconstitution of photosynthetic water splitting in inside-out thylakoid vesicles and identification of a participating polypeptide. Biochim. Biophys. Acta 681, 1-10 (1982) 